\title{
Predicted Responses of Beaches, Bays, and Inner-Shelf Sand Supplies to Potential Sea Level Rise (0.5-1.0 m) in Three Small Littoral Subcells in the High-Wave-Energy Northern Oregon Coast, USA
}

\author{
Curt D. Peterson ${ }^{1}$, Debra L. Doyle ${ }^{1}$, Charles L. Rosenfeld ${ }^{2}$, \& Kara E.P., Kingen ${ }^{1}$ \\ ${ }^{1}$ Geology Department, Portland State University, Portland, United States \\ ${ }^{2}$ Department of Geography, Environmental Sciences, and Marine Resource Management, Oregon State University, \\ Corvallis, United States \\ Correspondence: Curt Peterson, Geology Department, Portland State University, Portland, OR., 97207, United \\ States. Tel: 1-503-730-9266. E-mail: curt.d.peterson@gmail.com
}
Received: April 1, 2020
Accepted: June 28, 2020
Online Published: August 31, 2020
doi:10.5539/jgg.v12n2p1
URL: http://dx.doi.org/10.5539/jgg.v12n2p1

The research is financed by the National Coastal Resources and Development Institute, and the NOAA Office of Sea Grant and Extramural Programs.

\begin{abstract}
Three small subcells (Nehalem, Tillamook, and Netarts) totaling $\sim 55 \mathrm{~km}$ shoreline length in the high-wave energy northern Oregon coast are evaluated for potential beach sand loss from sea level rise (SLR) of 0.5-1.0 m during the next century. The predicted erosion is based on beach sand displacement from the narrow beaches (average $\sim 120 \mathrm{~m}$ width) to increased submarine accommodation spaces in the innermost-shelf (to $30 \mathrm{~m}$ water depth) and in the subcell estuaries (Tillamook Bay, Netarts Bay, and Nehalem Bay), following predicted near-future SLR. Beach sand sources from local rivers, paleo-shelf deposits, and/or sea cliff retreat are discriminated by distinctive heavymineral tracers. Modern beach sands in the study area are derived from river sand $(\sim 75 \%)$ and paleo-shelf sand $(\sim 25 \%)$. The supplies of paleo-shelf sand to the beaches have largely diminished in late-Holocene time. The riverenriched beach sands have been transported offshore to the inner-shelf $(0-50 \mathrm{~m}$ water depth) to fill increasing accommodation space in the inner-shelf during latest-Holocene conditions of relative SLR $\left(1.0 \mathrm{~m} \mathrm{ka}^{-1}\right)$. To evaluate the beach sand response to future SLR, representative beach profiles $(n=17)$ and intervening beach segment distances were compiled to yield beach sand volumes above mean lower low water (MLLW) or shallower wavecut platforms 'bedrock'. Across-shore cross-sectional areas, as averaged for each subcell, are as follows; Cannon Beach $\left(304 \mathrm{~m}^{2}\right)$, Tillamook $\left(683 \mathrm{~m}^{2}\right)$, and Netarts $\left(227 \mathrm{~m}^{2}\right)$. Littoral sand displacements to the adjacent innermostshelf (to $30 \mathrm{~m}$ water depth) and the marine-dominated areas of the three estuaries are based on assumed vertical sand accretion rates of $1.0 \mathrm{~m}$ per century and a conservative value of $0.5 \mathrm{~m}$ per century. The filling of such submarine accommodation spaces will displace all active-beach sand reserves in all three subcells for either the $1.0 \mathrm{~m}$ or $0.5 \mathrm{~m}$ thickness accommodation space scenarios. Large beach sand deficits, primarily from the filling of offshore accommodation spaces, could cause further retreat of soft-shorelines, including barrier spit and beach plain/dune deposits, in the Tillamook subcell (150-280 m) and in the southern half of the Netarts subcell (370-770 $\mathrm{m})$. The accommodation space approach used to predict beach sand volume loss from future SLR should have broad applicability in complex littoral systems worldwide.
\end{abstract}

Keywords: Beach Sand Erosion, Sea Level Rise, Submarine Accommodation Spaces

\section{Introduction}

In this article, the erosional fates of narrow sandy beaches, facing near-future sea level rise, are predicted for three adjacent littoral subcells: Cannon Beach, Tillamook, and Netarts, in the high-wave-energy setting of the northern Oregon coast (Figure 1). Shoreline retreats from sea level rise (SLR) have been predicted for sandy beaches in other settings by various methods (Wilcoxen, 1986; Bruun, 1988; Shaw et al., 1998; Zhang et al., 2004; Stive, 2004; Walkden and Dickson, 2008; Brunel and Sabatier, 2009; Erlandson, 2012; Masselink and Russell, 2013; Anderson et al., 2015; Romine et al., 2016; Toimil et al., 2017). Such predictions have not been reported for narrow sea cliff-backed beaches in the Pacific Northwest (PNW) study region. In this article, a coastal reach $(54.5 \mathrm{~m}$ in length), including three different subcells, with characteristically high-wave energy (peak Hs 10-15 m), narrow 
beaches (average $\sim 120 \mathrm{~m}$ width), and modest across-shelf gradients $(\sim 1.0 \%)$, are used to explore potential impacts of future SLR in the study region. The three subcells vary in 1) present beach widths, 2) localized Holocene dune development, 3) river versus paleo-shelf sand supply, and 4) estuarine sand sinks. The study region was supplied by continental shelf sand during the mid-Holocene marine transgression (Scheidegger et al., 1971) and by alongshore redistributions of mixed shelf, river, and eroded sea cliff sand during late-Holocene time (Peterson et al., 2009). One troubling similarity that all three subcells share is the evidence of declining littoral sand reserves in latest-Holocene time (Hart \& Peterson, 2007; Peterson et al., 2019). Some sand is lost to the estuaries (Hunger, 1966; Glenn, 1978) and to net alongshore transport (northward) out of the linked subcell systems. However, recent studies in the nearby Columbia River littoral cell (CRLC) demonstrate that littoral sand sedimentation rates in the innermost-shelf (to $\sim 30 \mathrm{~m}$ modern water depth) kept pace with sea level rise $\left(\sim 1.0 \mathrm{~m} \mathrm{ka}^{-1}\right)$ during latest-Holocene time (Peterson et al., In Press). Littoral sand from the Columbia River was effectively transported, and deposited, across the inner-shelf due to increasing offshore accommodation space, resulting from latest-Holocene SLR. Predicted future SLR, from ongoing global warming (Horton et al., 2014; Mengel et al., 2016; Deconto \& Pollard, 2016; Hansen et al., 2016; Kopp et al., 2019; Bamber et al., 2019; Horton et al., 2020) would increase offshore (inner-shelf) and inshore (estuary) sand accumulation spaces in the three-subcells study area, at the expense of beach sand deposits. In this article, we establish the recent sand supplies and existing sand volumes in the three different subcells for comparisons to estimated littoral sand losses to the offshore and estuarine sand sinks, following potential future SLR of 0.5 and $1.0 \mathrm{~m}$. Due to the small beach sand volumes, relative to potential increases in innermost-shelf accommodation spaces, the consequences of substantial SLR to the narrow sea-cliff and barrier-backed beaches in the three-subcells study area are predicted to be catastrophic. Such severe beach erosion would eliminate a public natural resource that is a central attraction to residents and the tourism industry in the region. The accommodation space approach demonstrated in this article should have direct application to further studies of near-future beach sand erosion in the larger Pacific Northwest region and to other coastlines around the world.

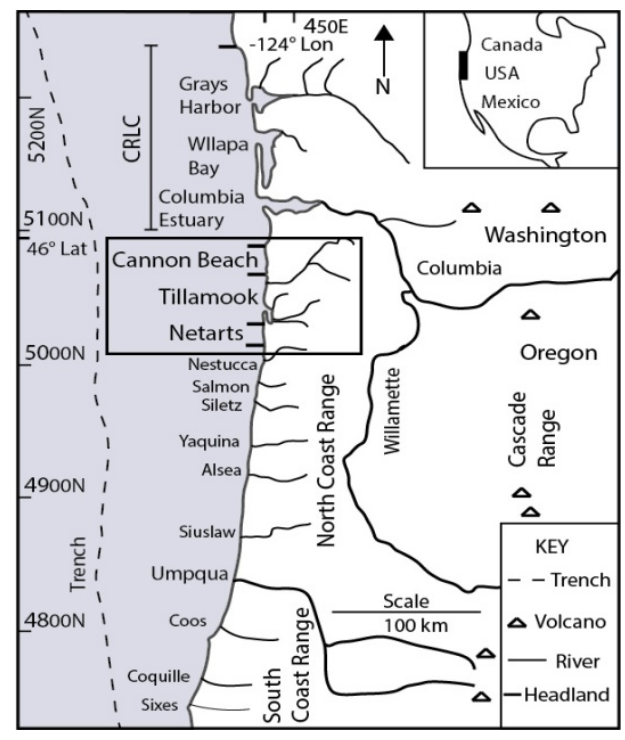

Figure 1. Map of study region

Mapped study region features include, the offshore Cascadia subduction zone buried trench (dashed line), the Cascade volcanic arc (volcanoes), and uplifted Coast Ranges. Antecedent rivers (bold lines), including the verylarge Columbia/Willamette Rivers and the large Umpqua River, cut across the Coast Ranges to intercept the Cascade volcanic arc. Small coastal rivers (lines) drain basaltic and metamorphic rocks, respectively, in the North and South Coast Ranges (Scheidegger et al., 1971). Headlands (bold lines) separate small littoral subcells, including the Cannon Beach, Tillamook, and Netarts subcells (Peterson et al., 1991), in the three-subcells study area (box). The Columbia River Littoral Cell (CRLC) system, contains four subcells that are divided by the verylarge Columbia River, Willapa Bay, and Grays Harbor estuaries. See Figure 2 for river names in the three-subcells study area. 


\section{Background}

\subsection{Subcell Morphology}

The three subcells used to examine the relations between potential SLR and beach sand volume loss include the Cannon Beach subcell (headland -to- headland distance= $14.5 \mathrm{~km}$ length), the Tillamook Subcell ( $25.5 \mathrm{~km}$ length), and the Netarts subcell (14.5 km length) (Figure 2). Seasonal mid-beach sand sizes (mean $\pm 1 \sigma$ ) for the modern beach deposits from the same sites in the three subcells are, summer $0.174 \pm 0.019 \mathrm{~mm}(\mathrm{n}=9)$ and winter $0.277 \pm 0.109 \mathrm{~mm}(\mathrm{n}=8)$ (Peterson et a., 1994). In addition to high-wave energies, the subcells are influenced by semi-diurnal meso-tidal ranges $(\sim 3.0 \mathrm{~m})$ and strong onshore winds (sustained winds $\geq 8 \mathrm{~m} \mathrm{~s}^{-1}$ ) during winter storms (Byrnes \& Li, 1998). Bounding headlands that separate the three subcells have the following seaward projection distances (south side): Tillamook Head $(1.4 \mathrm{~km})$, Cape Falcon-Neahkanie $(2.3 \mathrm{~km})$, Cape Meares $(0.6 \mathrm{~km})$, and Cape Lookout $(2.7 \mathrm{~km})$. Reported modern beach widths, measured from the beach face at mean tidal level (MTL) to backshore back-edges range from 20 to $260 \mathrm{~m}$ in the three subcells (Peterson et al., 1994). The narrow beaches in the Cannon Beach subcell $(80 \pm 40 \mathrm{~m} \mathrm{1 \sigma}, \mathrm{n}=30)$ are backed by sea cliffs. The wider beaches in the Tillamook subcell $(140 \pm 50 \mathrm{~m} 1 \sigma, \mathrm{n}=53)$ are predominantly backed by sandy barrier ridges, bay sand spits, and overlying dune deposits. Narrow beach widths in the Netarts subcell $(110 \pm 70 \mathrm{~m} 1 \sigma, \mathrm{n}=34)$ are evenly divided between sea cliffs to the north and the Netarts Bay sand spit to the south. The southern extent of the Netarts Bay spit is undergoing net erosion, resulting in truncated parabolic dune limbs and narrowing beach widths (Minor and Peterson, 2016). Semi-resistant sea cliffs, including Tertiary mudstones and weakly-cemented Quaternary deposits in the region (Figure 1), show modest historic retreat $\left(\sim 0.3 \mathrm{~m} \mathrm{yr}^{-1}\right)$ (Priest, 1999; Allan et al., 2003; Priest \& Allan, 2004). However, sea cliff retreat rates vary widely between different sea cliff types, including resistant basaltic headlands, Tertiary mudstones, active landslide areas, and weakly-cemented late-Pleistocene dune deposits. In addition to the Holocene barrier spits that protect the Nehalem, Tillamook, and Netarts Bays, a large Holocene sand ramp occurs at the northern end of the Tillamook subcell (Peterson et al., 2007), and much smaller Holocene sand ramps occur at the north ends of the Cannon Beach and Netarts subcells, as described further below.

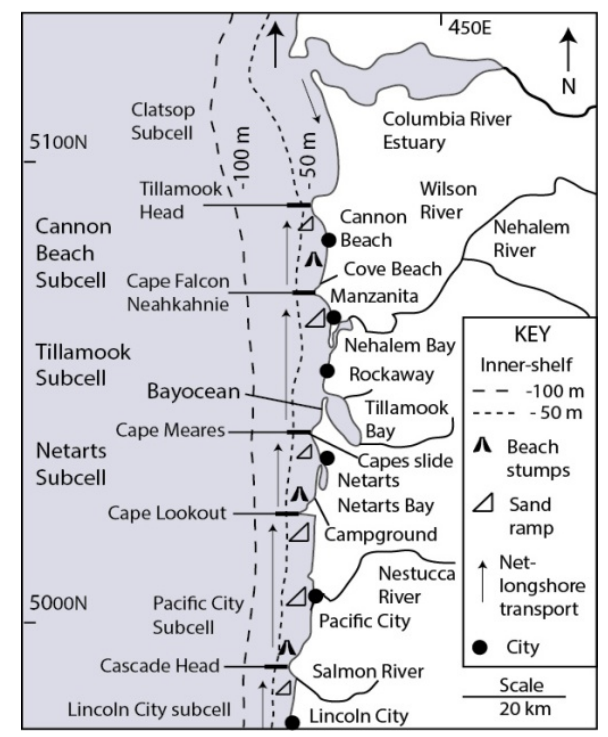

Figure 2. Map of study area

Mapped study area features include, subcell beaches between headlands (black bar), shelf bathymetric contours (dashed lines), eroding buried beach stumps (1-3 ka in age), and Holocene sand ramps (triangles). The small sand ramps located in the Cannon Beach subcell (26 m elevation at UTM 5083870N, 425264E and just south of Cascade Head in the Lincoln City subcell (100 m elevation at 4987280N, 420934E) did not exceed the $\sim 0.5 \mathrm{~m}$ length minimum to be reported by Peterson et al., (2019), but they are included in this smaller-size study area. The tall sand ramp located just south of Cascade Head is described in Peterson and Peterson (2020). The basal truncation of late-Holocene sand ramps by storm surf leads to 'perched' dunes on sea cliff tops for most of the ramp sites. Beach platform stumps (Hart and Peterson, 2007) also show evidence of declining beach sand supply and net beach erosion in the subcells. 
During marine low-stand conditions in latest-Pleistocene time, northward littoral transport along the midcontinental shelf $(\sim 100 \pm 50 \mathrm{~m}$ present water depth) conveyed sand northward (Scheidegger et al., 1971) to a major shelf bight (catchment) on the central Oregon coast (Peterson et al., 2007), and in much smaller volumes to slightlydivergent mid-shelf contours offshore of the northern Oregon Coast (Figures 1 and 2). Some shelf sand was transported by eolian processes across the emerged inner-shelf during marine low-stands to supply late-Pleistocene dune sheets ( $75-11 \mathrm{ka}$ in age). During the following middle-Holocene marine transgression ( $\sim 7 \pm 2 \mathrm{ka})$ asymmetric wave transport delivered paleo-shelf sand to the nearshore, feeding paleo-beaches, coastal dunes, and proto-bay spits and barriers (Glenn et al., 1978; Peterson et al., 2007). The inner-shelf is presently covered by sand (Runge, 1966), though the post-transgressive sand thickness is not established in the three-subcells study area. Modern inner-shelf gradients of $\sim 1.0 \%$ extend to $50 \mathrm{~m}$ depth at $\sim 5 \mathrm{~km}$ distance offshore in the study area.

During late-Holocene time, weakening alongshore transport preferentially trapped some beach sand at the northern ends of headland bounded subcells in the study area. These late-Holocene catchments lead to 1) upland dune fields at the north end the Tillamook subcell and 2) smaller sea cliff sand ramps at the north ends of all three subcells (Figure 2) (Peterson et al., 2009; 2019). The consistent positions of dune fields and sea cliff sand ramp placements at the northern ends of the subcells establish slight net-northward littoral transports during late-Holocene time (5$0 \mathrm{ka}$ ). However, all of the smaller sand ramps now show evidence of partial to complete basal truncation by storm surf, indicating more-recent net beach erosion, as addressed further below in Section 2.3.

Although wave directions generally reverse seasonally (from the southwest in winter and from the northwest in winter) in the study area (Figure 2), dominant forcing from the southwest does occur during El Niño events, as shown by intensified northward longshore sand transport. Two high-index El Niño events in 1983 and 1998 lead to significant beach erosion at the south ends of all three of the study area subcells (Rosenfeld et al., 1991; Revell et al., 2002). The eroded beaches at the south ends of the Cannon Beach and Tillamook subcells have made partial recoveries to pre-1983 conditions, however no beach recovery has occurred at the south end of the Netarts subcell, located just north of the largest headland, Cape Lookout (Minor and Peterson, 2016). Episodic northward sand bypassing around the largest headlands is inferred to occur at century time scales, based on beach sand mineralogy (see Section 4.1 below).

\subsection{Estuary Sand Sinks and Sources}

The three meso-tidal estuaries in the study area, including Nehalem, Tillamook, and Netarts Bays (Figure 2), demonstrate wide ranges in size, hydrography, and sandy sediment accumulation (Table 1). Netarts Bay is of modest size, including a mean high water (MHW) surface area of $9.4 \mathrm{~km}^{2}$. With no river sediment input, the Netarts lagoon is largely in-filled to intertidal levels with littoral sand. Tillamook Bay is the largest estuary $\left(33.5 \mathrm{~km}^{2}\right)$ that is hosted entirely in Oregon. Several small rivers enter Tillamook Bay, contributing sediment from a combined drainage basin area of $1,400 \mathrm{~km}^{2}$ (Karlin, 1980). However, a moderately large tidal:fluvial hydrographic ratio (Hr $=36$ ), as defined in Table 1, suggests sufficient flood tidal current flow to import some littoral sand into the subtidal channels and lower intertidal sand flats of Tillamook Bay. Shallow seismic profiling, drill coring, and deposit ${ }^{14} \mathrm{C}$ dating have been performed in Tillamook Bay (Glenn, 1978). Textural and heavy-mineral analyses of representative core samples were used to establish the littoral sand components in the late-Holocene bay fill (Peterson and Darienzo, 1989). Those data are used in this article (Section 4.3) to calculate the relative proportions of river and beach sand supply to Tillamook Bay in late-Holocene time. The Nehalem River drainage basin is relatively large in size $\left(1730 \mathrm{~km}^{2}\right)$, relative to its MHW surface area $\left(9.7 \mathrm{~km}^{2}\right)$. This relation led to substantial infilling of the ancestral valley and corresponding broad floodplains that constrict the upper estuarine channel reaches. River sand, rich in subangular lithic-fragments, currently extends along eastern bay shorelines to within $1.0 \mathrm{~km}$ of the Nehalem River mouth.

Table 1. Hydrographic parameters for Tillamook, Nehalem, and Netarts estuaries

\begin{tabular}{llll}
\hline Parameter & Tillamook Bay & Nehalem Bay & Netarts Bay \\
\hline Drainage basin area $\left(\mathrm{km}^{2}\right)$ & 1400 & 1730 & 30 \\
Basin suspended sed discharge $\left(\mathrm{t} \mathrm{yr}^{-1}\right)$ & 175,000 & 216,000 & - \\
Basin bedload discharge $\left(\mathrm{m}^{3} \mathrm{yr}^{1}\right)$ & 26,700 & 32,900 & - \\
Estuary MHW area $\left(\mathrm{km}^{2}\right)$ & 33.5 & 9.7 & 9.4 \\
Estuary Mean Tidal Level area $\left(\mathrm{km}^{2}\right)$ & 25.1 & 6.7 & 6.3 \\
Estuary MLW area $\left(\mathrm{km}^{2}\right)$ & 16.7 & 3.8 & 3.3 \\
Estuary Intertidal area \% & 50 & 53 & 65 \\
Estuary Hydrographic ratio $(\mathrm{Hr})$ & 36 & 10 & $>100$ \\
Estuary dominant bedload source & Mixed & River sand & Littoral sand \\
\hline
\end{tabular}


Notes: Drainage basin annual bedload discharges $\left(\mathrm{m}^{3} \mathrm{yr}^{-1}\right)$ are estimated from drainage basin suspended sediment discharges (Karlin, 1980), assuming bedload is $25 \%$ of the suspended load fractions and bedload sand mass to sand volume conversion ratios of 0.61 . Tidal level surface areas $\left(\mathrm{km}^{2}\right)$ and intertidal areas (\% of total) are from Percy et al. (1974). Hydrographic ratios (Hr) are calculated from the ratio of the average tidal prism volume to the annual river discharge normalized to a $6 \mathrm{hr}$ period (Peterson et al., 1991).

\subsection{Evidence of Declining Beach Sand Reserves}

There are four types of evidence that demonstrate gradually declining beach sand reserves in the study region. The first type involves the ongoing exposure of buried in-situ tree stumps at multiple beaches in the study area (Figure 2) (Hart and Peterson, 2007). During interseismic uplift cycles in the central Cascadia subduction zone (Darienzo \& Peterson, 1991; Peterson et al., 2000), late-Holocene wave-cut platforms in the study area were cyclically uplifted by as much as $1.5 \mathrm{~m}$. The cyclic uplift, probably assisted by freshwater seepage from adjacent sea cliffs, permitted the growth of conifers, reaching $0.5-1.5 \mathrm{~m}$ in diameter, on emerged wave-cut platforms. The platform forests were locally buried by episodic beach sand supply, generally between 5 and $2 \mathrm{ka}$, which protected the insitu stumps from subsequent coseismic-subsidence events and longer-term net sea level rise. However, progressive beach sand erosion in latest-Holocene time episodically exposes the stumps to wave attack, leading to sightings of 'mystery' stumps in the surf zones.

A second type of evidence that demonstrates declining beach sand supply is the ocean wave truncation of lateHolocene eolian sand ramps that were built-up against paleo-sea cliffs (Figure 2). Some of the sand ramps have been eroded to the degree that only 'perched dunes' remain on sea cliff tops (Peterson et al., 2019). Terminal sand depositions in the eolian sand ramps approximately date the onsets of beach/ramp retreats, eventually leading to ramp base truncations by storm surf. Near-terminations of the sand ramp developments are ${ }^{14} \mathrm{C}$ dated in the Netarts subcell (1.8 ka) and in the Pacific City subcell (north ramp $1.4 \mathrm{ka}$ and middle ramp $0.9 \mathrm{ka}$ ) (Peterson et al., 2019). The very-small sand ramp at the northernmost end of the Cannon Beach subcell receives episodic beach sand supply at its southernmost end (Breakers Point) due to lateral migrations of the Ecola Creek channel mouth (Rosenfeld, 1977), but the northern end of ramp is currently truncated by storm surf.

A third type of evidence involves the very-localized preservation of the last coseismic-subsidence beach retreat scarp (AD 1700) in the study region (Meyers et al., 1996). The abrupt subsidence event (1.0-1.5 m of relative SLR in the study area) was widespread throughout the three subcells (Peterson et al., 2000). However, a corresponding catastrophic beach retreat scarp was only preserved at the northern end of the Tillamook subcell (Figure 2), where $\sim 150 \mathrm{~m}$ of interseismic beach width recovery occurred from interplate recoupling and regional tectonic uplift, after $\sim 1750$ (Peterson et al., 2010). No preserved catastrophic beach retreat scarps have been found by these authors from any other beaches in the three-subcells study area. The narrow beaches in the three-subcells study area generally lacked sufficient sand supply to preserve the latest-Holocene records of past coseismic beach retreat scarps. With the exception of the northern Nehalem sand spit, any evidence of the last coseismic beach retreat and recovery cycle in the three-subcells study area, has been lost to net beach erosion during the last few centuries.

The fourth type of evidence involves late-historic events of beach, barrier, and/or sea cliff erosion in the study area (Figure 2). These events include, among others: 1) jetty-related erosion of the Bayocean Resort (1920s-1930s) and a temporary breach (1952) of the Tillamook Bay south sand spit (Terich, 1973), 2) chronic erosion of beach protective structures and protective rock revetments (1983-present) at the south-end of the Netarts subcell (Minor \& Peterson, 2016), 3) a dramatic sandy sea cliff landslide in the Capes development (1997-1998) at the north end of the Netarts subcell (Percy et al., 1998; Priest, 1998; Peterson et al., 2019), and 4) episodic beach sand erosion (2000-present) in the Rockaway barrier ridge in the central part of the Tillamook subcell, leading to constructed rip-rap revetments (Horning, 2006). Though the late-historic events of beach erosion vary in locations and dates, they do collectively establish an ongoing vulnerability of the study area beaches to episodic erosion from different forcing factors. In this article, we evaluate the erosional susceptibility of the study area beaches to potentiallyrapid SLR $(0.5-1.0 \mathrm{~m})$ in the near future.

\section{Methods}

Heavy-mineral analyses establish broad lithologic provenances and corresponding shelf and river sources of beach sand in the study region (Scheidegger et al., 1971). In this article, sand samples were separated in Na-polytungstate (spg 3.0) under centrifuge for heavy- and light-mineral separations. Heavy-minerals were mounted in picolyte ${ }^{\mathrm{TM}}$ for petrographic counting at 250x, including at least 300 mono-mineralic grains per slide in randomized transects. Ratios of hypersthene:augite and metamorphic amphiboles:augite are used to discriminate between paleo-shelf and river sources of modern beach sand. The metamorphic amphiboles used here include blue-green hornblende, actinolite, and tremolite. Only strongly-colored/pleochroic orthopyroxene grains are counted as hypersthene here, 
resulting in slightly lower hypersthene counts relative to Scheidegger et al. (1971).

Beach sand volumes in representative across-shore transects were estimated by beach sand profiling to the wavecut platform or to subsurface depths equivalent to mean lower low water (MLLW), which is $-1.5 \mathrm{~m}$ mean tidal level (MTL) or $-0.5 \mathrm{~m}$ NAVD88. Beach toes commonly occur at the MLLW tidal elevation in the study region. The back-shore back-edge is taken to be at the beach sand intersection with a sea cliff or shore-stabilization structure, typically about $5 \mathrm{~m} \mathrm{MTL}$, or about mid-slope on the seaward side of a foredune $(\sim 50 \%$ vegetation cover/stabilization). These are the defined bounds for active-beach sand volumes in the study area. Continuous beach width measurements were made with aerial photography/videography in 1989-1991, by measuring acrossshore distance between the back-shore back-edges and the mid-swash zone, imaged at the time of predicted MTL \pm 1 hour, during summer months (Rosenfeld et al., 1991). These data were used to select 'most representative' sites within multi-kilometer intervals for beach profile surveying (1990-1991). The MTL elevation is the most convenient/precise tidal level datum to measure beach width from aerial surveys of timed (predicted) mid-swash zone runup, due to the relatively steep beach faces that reduce swash horizontal excursions (Rosenfeld et al., 1991).

Beach profile locations were selected on the bases of similar alongshore interval distances, beach access, and similarity to averaged beach widths, as measured at $500 \mathrm{~m}$ spacings alongshore by aerial photo/videography (Rosenfeld et al., 1991). The selection of a profile location with a similar beach width to the averaged beach widths within the larger beach segment reduced bias from large-scale beach width variability (Peterson et al., 1991). Across-shore beach profiling was performed with an EDM total station $( \pm 1 \mathrm{~cm})$ (Pettit, 1990; Doyle, 1996; Percy et al., 1998). Three across-shore beach profiles were collected within a 50-100 m alongshore distance at each profile location. The profiles were either averaged or the intermediate-width profile was selected to reduce bias from local beach width variability (Pettit, 1990).

Profile elevations were tied into predicted tide levels from mid-swash runups ( $\pm 0.25 \mathrm{~m}$ error) measured during the time of predicted mean tide level (MTL \pm 0.1 hour). Beach sand thickness was established at multiple backshore and mid-beach sites by 1) seismic refraction and trenching in the Cannon Beach subcell (Pettit, 1990; Peterson et al., 1991) and 2) ground penetrating radar (GPR) and sand augering (Tillamook and Netarts subcells) (Doyle, 1996; Peterson et al., 2010). GPR was also used to test for coseismic beach retreat scarps in the Nehalem Bay, Tillamook Bay, and Netarts Bay sand spits (H. Jol and C. Peterson, unpublished data, 2001; Losey, 2003; Peterson et al., 2010). Littoral sand extends well below the MLLW elevation, to at least $-5 \mathrm{~m}$ MTL, in the sandy barrier-backed beaches in the Tillamook and the Netarts subcells. Shallow wave-cut platforms in the Cannon Beach subcell and northern Netarts subcell were ground-truthed in hand-shoveled (trench) pits. Modern barrier spit and dune ridge topography data in the three subcells are from bare ground lidar (2009) with reported $0.1 \mathrm{~m}$ vertical accuracy (DOGAMI, 2019).

Sediment texture (grain-size classes) and sand sources (river versus littoral) in Tillamook Bay are established from drill core data (Glenn, 1978; Peterson \& Darienzo, 1989). Relative abundances of mud, sand, and gravel size fractions in recovered drill core samples were established by wet sieving at 0.062 and $2.000 \mathrm{~mm}$ screen sizes (Folk, 1980). Sand sources are based on heavy-mineral analysis (hypersthene: augite ratios) as described above. Deposit size fractions (mud and sand) for Netarts Bay are taken from Hunger (1966). No size class data are available for the surface deposits in Nehalem Bay, so the estimated sand fraction percent coverage in Tillamook Bay is used as a proxy for Nehalem Bay.

Inner-shelf profiles (east-west) are taken from online DEMs (Google Earth, 2020). Several representative profiles are presented for the Cannon Beach, Tillamook, and Netarts subcells, and the bounding headlands, and the estuary ebb tide deltas. Averaged across-shelf gradients are computed for profiles extending to 30 and $50 \mathrm{~m}$ bathymetric depths in the representative inner-shelf profiles. Inner-shelf accommodation spaces for eroded beach sand from each subcell are based on bounded offshore surface areas. The seaward bounds are the innermost-shelf $30 \mathrm{~m}$ depth or bathymetric contours between bounding headlands. The landward bounds are defined by $1.0 \mathrm{~km}$ east-west distances from the beach shoreline (MTL). The $1.0 \mathrm{~km}$ offshore distance represents $\sim 1 / 3$ of the innermost-shelf width $(\sim 3 \mathrm{~km})$, or the transition zone between shoreward erosion and seaward accumulation following SLR, as taken from equilibrium profile translations (Bruun, 1962). Repeated digitization of the innermost-shelf accommodation surface areas yielded maximum differences (errors) of up to 0.8 percent.

\section{Results}

\subsection{Regional Beach Sand Sources}

In this study, mono-mineralic pyroxenes (augite and hypersthene) and metamorphic amphiboles (blue-green hornblende, actinolite and tremolite) are used to discriminate between beach sand sources, including local rivers and paleo-shelf sand supply (Table 3). The relative abundances of these mineral tracers are presented in Regional 
Heavy Mineral Data in Supplemental Materials. Augite is supplied to all of the smaller rivers in the North Coast Range (Figure 3), including the Nehalem, Wilson, Nestucca, and Salmon Rivers from uplifted North Coast Range basalts. The hypersthene:augite ratios in the North Coast Range rivers range from 0.0 to 0.1 . Hypersthene has been supplied to the continental shelf by large antecedent rivers, such as the Columbia and Umpqua Rivers, which drain intermediate volcanic rocks in the Cascade volcanic arc (Scheidegger et al., 1971). The hypersthene:augite ratios in the large antecedent rives (Columbia and Umpqua Rivers) that intercept the Cascade volcanic arc range from 0.7 to 0.9 . The surface deposits of the mid- and inner-shelf vary along-shelf and across-shelf in the relative abundances of metamorphic amphiboles, hypersthene, and augite. Understandings of these spatial trends are needed to estimate the relative contributions of river and shelf sand supply to the nearby beaches. Surface deposits of the mid-shelf show northward dispersal of hypersthene-enriched sands from the mouths of the Columbia and Umpqua Rivers (Scheidegger et al., 1971; Venkatarathnam \& McManus, 1973). The metamorphic amphibole:augite ratio in the Sixes River, representative of the South Coast Range rivers, is 2.2 (Table 3). The South Coast Range rivers delivered metamorphic amphiboles to the continental shelf, where they were dispersed northward along the mid-shelf, offshore of northern Oregon. The timings of these northward dispersals on the shelf were not well established by Scheiddegger et al. (1971), but analyses of dated paleo-dune sheets in the study area (Peterson et al., 2007) do constrain the timings of mid-shelf sand compositions relative to marine low-stand and transgressive conditions, as presented below.

Table 3. Selected heavy-mineral abundances in river, sea cliff paleo-dune, and beach deposits

\begin{tabular}{|c|c|c|c|c|c|c|c|}
\hline $\begin{array}{l}\text { Settings/UTM-N } \\
\text { (m) }\end{array}$ & $\begin{array}{l}\text { Dune age } \\
(\mathrm{ka})\end{array}$ & $\begin{array}{l}\text { Sand size } \\
(\mathrm{mm})\end{array}$ & $\begin{array}{l}\text { Aug } \\
(\%)\end{array}$ & $\begin{array}{l}\text { Hyp } \\
(\%)\end{array}$ & $\begin{array}{l}\text { MetaAmph } \\
(\%)\end{array}$ & $\begin{array}{l}\text { Hyp:Aug } \\
\text { ratio }\end{array}$ & $\begin{array}{l}\text { MetaAmph:Aug } \\
\text { ratio }\end{array}$ \\
\hline \multicolumn{8}{|l|}{ Rivers } \\
\hline Columbia & & & 26 & 18 & 12 & 0.7 & 0.5 \\
\hline Nehalem & & & 78 & 7 & 1 & 0.1 & 0.0 \\
\hline Wilson & & & 81 & 5 & 1 & 0.1 & 0.0 \\
\hline Nestucca & & & 85 & 2 & 1 & 0.0 & 0.0 \\
\hline Salmon & & & 82 & 1 & 3 & 0.0 & 0.0 \\
\hline Siletz & & & 83 & 0 & 1 & 0.0 & 0.0 \\
\hline Alsea & & & 85 & 2 & 1 & 0.0 & 0.0 \\
\hline Siuslaw & & & 66 & 4 & 2 & 0.1 & 0.0 \\
\hline Umpqua & & & 32 & 28 & 7 & 0.9 & 0.2 \\
\hline Sixes & & & 19 & 5 & 41 & 0.3 & 2.2 \\
\hline \multicolumn{8}{|l|}{ Sea cliff dune } \\
\hline 5033200 & Pleis. & & 31 & 12 & 23 & 0.4 & 0.7 \\
\hline 5017000 & $11.2 \pm 1.5$ & & 30 & 18 & 18 & 0.6 & 0.6 \\
\hline 4979090 & $73.3 \pm 4.5$ & & 29 & 14 & 20 & 0.5 & 0.7 \\
\hline 4929650 & $62.6 \pm 4.1$ & & 32 & 22 & 15 & 0.7 & 0.5 \\
\hline 4834890 & $30.6 \pm 5.4$ & & 32 & 25 & 14 & 0.8 & 0.4 \\
\hline \multicolumn{8}{|l|}{ Subcell Beaches } \\
\hline \multicolumn{8}{|l|}{ CRLC Clatsop } \\
\hline 5110100 & & 0.204 & 25 & 19 & 11 & 0.8 & 0.4 \\
\hline \multicolumn{8}{|l|}{ Cannon Beach } \\
\hline 5084500 & & 0.208 & 50 & 10 & 7 & 0.2 & 0.1 \\
\hline 5077900 & & 0.216 & 52 & 12 & 5 & 0.2 & 0.1 \\
\hline \multicolumn{8}{|l|}{ Tillamook } \\
\hline 5064500 & & 0.221 & 58 & 15 & 4 & 0.3 & 0.1 \\
\hline 5052300 & & 0.272 & 57 & 11 & 4 & 0.2 & 0.1 \\
\hline \multicolumn{8}{|l|}{ Netarts } \\
\hline 5033400 & & 0.197 & 62 & 14 & 3 & 0.2 & 0.0 \\
\hline 5030100 & & 0.21 & 64 & 15 & 4 & 0.2 & 0.1 \\
\hline \multicolumn{8}{|l|}{ Pacific City } \\
\hline 5013400 & & 0.239 & 60 & 15 & 3 & 0.3 & 0.1 \\
\hline \multicolumn{8}{|l|}{ Other beaches } \\
\hline 497900 & & 0.276 & 63 & 12 & 5 & 0.2 & 0.1 \\
\hline 4950100 & & 0.269 & 44 & 25 & 7 & 0.6 & 0.2 \\
\hline 4937900 & & 0.239 & 40 & 20 & 6 & 0.5 & 0.2 \\
\hline 4832400 & & 0.349 & 37 & 30 & 10 & 0.8 & 0.2 \\
\hline
\end{tabular}

Notes. UTM North positions are in meters (m). Pleistocene dune thermoluminescence ages (ka) are from 
Wiedemann (1990) for the S. Capes Lookout site, and from Peterson et al. (2007) for all other sea cliff dune deposit sites. Mean grain sizes of beach sands (beach face) are in millimeters (mm). Heavy-minerals include 1) monomineralic pyroxenes, augite (Aug) and hypersthene (Hyp), and 2) Metamorphic amphiboles (MetaAmph) including blue-green hornblende, actinolite, and tremolite (but not glauconite). Only strongly colored or pleochroic orthopyroxene grains were counted as hypersthene in this study, thereby slightly reducing hypersthene counts relative to Scheidegger et al. (1971). Mineral relative abundances are shown as percents of total counted heavyminerals (total 250-300 grain count per sample) (Regional Heavy Mineral Data in Supplemental Materials).

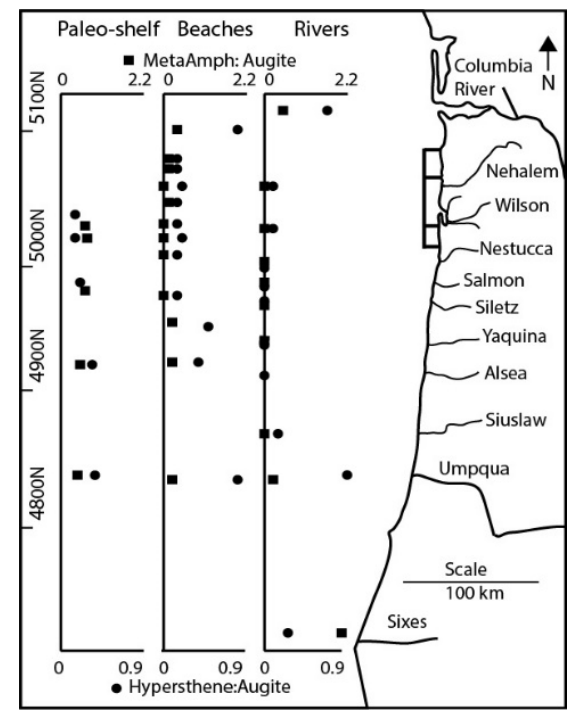

Figure 3. Along-shore plots of heavy-mineral tracers

Along-shore heavy-mineral plots include hypersthene:augite ratios (0-0.9) andMetaAmph:augite ratios (0-2.2) in sand samples from 1) rivers, 2) late-Pleistocene dune deposits in sea cliffs and 3) modern beaches, as functions of positions along the coast in the study region (km UTM-N). Metamorphic amphiboles (MetaAmph) include bluegreen hornblende, actinolite, and tremolite. The three-subcell study area (boxed) is shown with subcell headlands (bars). See Table 3 for summarized mineral ratios and Regional Heavy Mineral Data in Supplemental Materials for relative mineral abundances.

Representative late-Pleistocene dune sheet deposits ( 11-73 ka) were sampled from sea cliffs in the study region (Table 3 and Figure 3) (Peterson et al., 2007). The late-Pleistocene dune sheets developed from landward acrossshelf eolian transport during marine low-stand conditions of shelf emergence. Their heavy-mineral compositions should reflect the inner- and mid-shelf sand compositions that were remobilized and transported landward by eolian transport during late-Pleistocene time. Some of the paleo-shelf deposits were later remobilized and transported to the Holocene littoral systems by the mid-Holocene marine transgression (9-5 ka). The remnants of those late-Pleistocene dune sheets are currently exposed in retreating sea cliffs. The dune-sheet deposits range from 0.4 to 0.8 in hypersthene:augite ratios and 0.4 to 0.7 in metamorphic amphibole:augite ratios. The mineralogies of most beach deposits in the study area decrease in hypersthene:augite ratios with distance northward along the northern Oregon coast $(0.8-0.2)$. The modern beach sands generally fall in between the heavy-mineral compositions of adjacent river sand sources and the paleo-shelf sand sources. For example, the modern beach deposits in the three-subcell study area have an average hypersthene:augite ratio of 0.2 , which is between those of the river sand ratios of 0.0 and the averaged paleo-shelf ratio of 0.55 . The beach deposits average 0.1 in metamorphic amphibole:augite ratio, which is between the river values of 0.0 and the averaged paleo-shelf value of 0.62 . These two different beach and river endmember source ratios yield beach sand compositions of $64-83 \%$ $(\sim 75 \%)$ river sand source and $17-36 \%(\sim 25 \%)$ paleo-shelf sand source. The slightly-larger paleo-shelf component values derived from the hypersthene:augite ratios might reflect small northward dispersals of hypersthene-enriched sand on the inner-shelf in mid- to late-Holocene time. Such Holocene northward dispersals would not have been recorded in the late-Pleistocene dune sheet endmembers.

\subsection{Subcell Beach Profiles}

Profiles of active-beaches have been reported for 1) the Cannon Beach subcell (n=5) (Peterson et al., 1994), 2) the Tillamook subcell ( $\mathrm{n}=7$ ) (Doyle, 1996; Peterson et al., 2010), and 3) the Netarts subcell $(\mathrm{n}=7)$ (Percy et al., 1998; 
Minor and Peterson, 2016). These profiles extend from the foot of the exposed sea cliff or seaward side of the most recently stabilized foredune ( $>50 \%$ vegetation cover) to the beach face intersection with MLLW, usually coinciding with the beach toe. The reported profiles are used in this study to evaluate existing active-beach sand volumes in the Cannon Beach, Tillamook, and Netarts subcells (Figure 4). Representative profiles from those three subcells are shown in Figures 5 and 6. The beach profiling included subsurface geophysical testing, sand augering, and/or trenching (Peterson et al., 1991) to establish subsurface depths to basal conglomerates or indurated wavecut platforms 'bedrock'. For this study, beach sand thicknesses are established from subsurface depths to either the underlying wave-cut platform or to the MLLW tidal elevation (-1.5 m MTL), depending on which is shallowest. The beach profiles, mostly collected in the 1990s, lacked sufficient position and elevation accuracy for beach retreat monitoring. Recent lidar coverages (2009 and 2012) in the study area (DOGAMI, 2019) are available for comparison to future lidar surveys to evaluate future beach retreat, but those data do not provide constraints on the underlying beach sand thicknesses. Unconsolidated beach sand thicknesses, as measured to the underlying beach platforms or the MLLW elevation, range widely $(\sim 0.5-5 \mathrm{~m})$ in the study area. The variability in platform depth is as important to beach sand volume as is the variability in beach width or beach slope in the study region (Peterson et al., 1991).

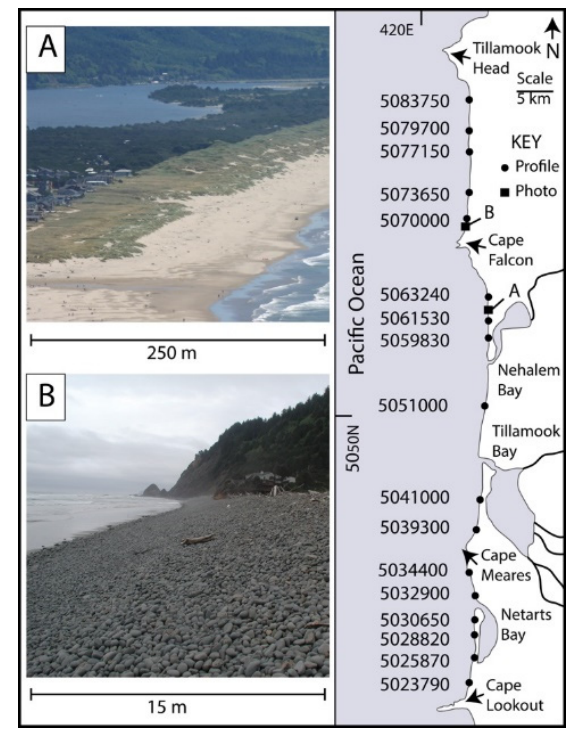

Figure 4. Map of surveyed beach profiles in the study area

Profile sites (solid circles) and two beach photos (solid squares) taken in 1999, corresponding to Part A, profile 5061530 in a wide sandy beach at the north end of the Tillamook subcell (view south) and Part B, profile 507000 in a narrow cobble berm above an exposed wave-cut platform at the south end of the Cannon Beach subcell (view north), following the 1998 El Niño. See Figure 2 for subcell names between dividing headlands (arrows). See representative beach profiles plotted in Figures 5 and 6. Summarized profile data are presented in Table 4. 


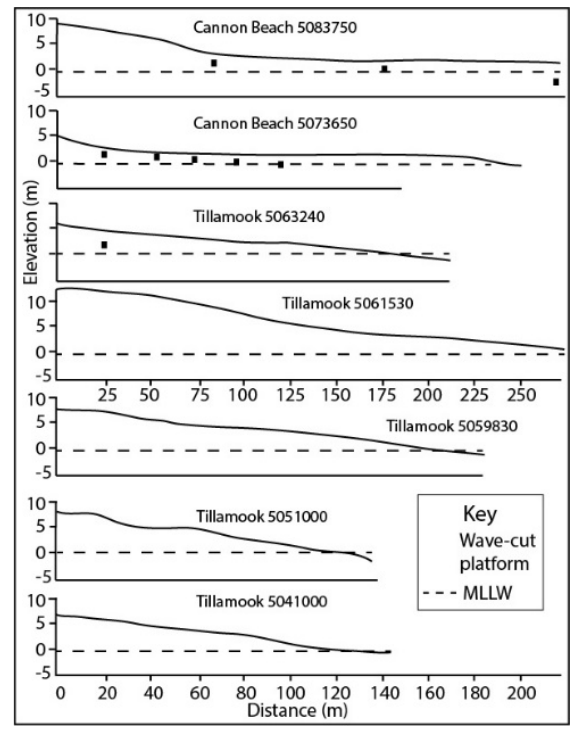

Figure 5. Surveyed active-beach profiles in the Cannon Beach and Tillamook subcells

Profile positions (latitudes) are shown in meters (m UTM-N). The wave-cut platforms (solid squares) were groundtruthed by auger drilling and/or shovel trenching. The Cannon Beach subcell profiles are redrawn from Peterson et al., 1991. The Tillamook subcell profiles are redrawn from Doyle (1996), with the exception of Tillamook 5061530 (25 m distance intervals), which is from Peterson et al. (2010). The elevation datum $(0 \mathrm{~m})$ is the mean lower low water (MLLW) tidal elevation, which is about $0.5 \mathrm{~m}$ below the $0 \mathrm{~m}$ NAVD88 vertical datum in the study area.

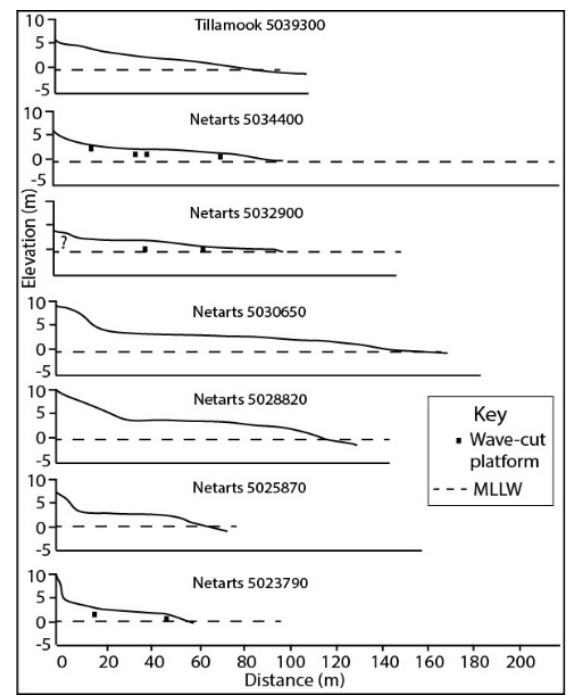

Figure 6. Surveyed active-beach profiles in the Tillamook and Netarts subcells

Profile positions (latitudes) are shown in meters (m UTM-N). The wave-cut platforms (solid squares) were groundtruthed by auger drilling and/or shovel trenching. The Tillamook profile 5038950 is from Doyle (1996). The three northernmost Netarts profiles were collected in 1998 (Percy et al., 1998). The Netarts bay spit profiles (no wavecut platforms) were collected in 2001. The southernmost profile was collected by Minor and Peterson (2016). The elevation datum $(0 \mathrm{~m})$ is the mean lower low water (MLLW) tidal elevation, which is about $0.5 \mathrm{~m}$ below the $0 \mathrm{~m}$ NAVD88 vertical datum in the study area.

The active-beach profile settings in the study area subcells are characterized by 1) latitude positions (UTM-N), 2) backshore back-edge conditions, 3) backshore elevations, 4) mid-beach platform depth, and 5) mid-beach sand 
grain-sizes (Table 4). The surveyed profiles are summarized for 1) beach widths, 2) average beach slopes, and 3) beach sand cross-section areas above MHHW and MLLW, and 4) beach segment lengths (Table 5). The beach segment lengths are taken between the corresponding mid-points between profile locations or between north/south terminal profiles and the limits of sandy beach extent near bounding headlands (Peterson et al., 1991). The averaged mid-beach platform 'bedrock' elevations in the three subcells are as follows: Cannon Beach $(-1.7 \mathrm{~m}$ MTL), Tillamook (below $-5 \mathrm{~m} \mathrm{MTL)}$, and Netarts ( 1.0 m MTL, fronting the sea cliffs and below $-5 \mathrm{~m} \mathrm{MTL,}$ along the Netarts Bay spit). The averages of profile beach widths (back-edge to beach face interception with the predicted MTL in the three subcells are as follows: Cannon Beach $(78 \mathrm{~m})$, Tillamook $(97 \mathrm{~m})$, and Netarts $(61 \mathrm{~m})$. The averaged sand cross-sectional areas above MHHW in the measured study area profiles are as follows: Cannon Beach subcell $\left(132 \mathrm{~m}^{2}\right)$, Tillamook subcell $\left(273 \mathrm{~m}^{2}\right)$, and the Netarts subcell $\left(22 \mathrm{~m}^{2}\right)$. These cross-sectional areas represent the sand reserves that buffer short-term wave attack on sea cliffs and foredunes (Peterson et al., 1991). A loss of this sand would result in swash zone flooding of the current summer sandy beaches during the highest tides. The averaged sand cross-sectional areas above the beach platform or MLLW in the measured study area profiles are as follows: Cannon Beach subcell $\left(304 \mathrm{~m}^{2}\right)$, Tillamook subcell $\left(683 \mathrm{~m}^{2}\right)$, and the Netarts subcell (227 $\mathrm{m}^{2}$ ). These cross-sectional areas represent the existing sand reserves above the wave-cut platforms or the MLLW tidal elevation. A loss of this sand would eliminate the current sandy beaches in the study area. That is to say that, either wave-cut platforms 'bedrock', basal cobble lag, or the MLLW level would fully extend across the currentlyexisting active-beach areas during all tidal levels.

Table 4. Subcell active-beach profile settings

\begin{tabular}{lllll}
\hline Subcell/UTM-N $(\mathrm{m})$ & Back-edge type & Backshore elev. (m MTL) & Platform depth (m MTL) & Beach sand size $(\mathrm{mean} \pm 1 \sigma \mathrm{mm})$ \\
\hline Cannon Beach & & & & \\
5083750 & FD & 5.5 & -1.5 & $0.166 \pm 0.026$ \\
5079700 & $\mathrm{SC}$ & 5.5 & -1.0 & $0.166 \pm 0.037$ \\
5077150 & $\mathrm{SC}$ & 5.5 & -2.0 & $0.187 \pm 0.034$ \\
5073650 & $\mathrm{SC}$ & 5.5 & -1.5 & $0.187 \pm 0.033$ \\
5070000 & $\mathrm{SC}$ & 1.5 & -2.5 & $0.152 \pm 0.045$ \\
Tillamook & & & \\
5063240 & FD & 5.0 & 0.5 & 0.221 \\
5061530 & FD & 5.5 & below -5.0 & $0.195 \pm 0.032$ \\
5059830 & FD/BS & 5.5 & below -5.0 & $0.207 \pm 0.042$ \\
5051000 & BD & 5.0 & below -5.0 & $0.270-$ \\
5041000 & FD/BS & 5.0 & below -5.0 & - \\
5039300 & FD/BS & 4.0 & below -5.0 & $0.167 \pm 0.037$ \\
Netarts & & & \\
5034400 & SC & 4.5 & 1.5 & $0.199 \pm 0.036$ \\
5032900 & SC & 3.5 & ? slope failure & $0.197-$ \\
5030650 & FD/BS & 4.5 & below -5.0 & $0.210-$ \\
5028820 & FD/BS & 4.5 & below -5.0 & - \\
5025870 & FD/BS & 4.0 & below -5.0 & - \\
5023790 & SC & 3.5 & 0.5 & $0.182 \pm 0.035$ \\
\hline
\end{tabular}

Notes: Back-edge of backshore conditions include, sea cliff (SC), foredune (FD), bay spit (BS), barrier dune-ridge (BD). Backshore sand elevations (m MTL) are taken from the highest backshore sand deposits or base of the foredune. Platform depth (m MTL) is taken from measured elevations of basal cobbles or indurated stratum 'bedrock' in mid-beach profile positions. Mid-beach or back-berm sand samples (summer) are from surveyed profiles in the Cannon Beach subcell (Pettit, 1990) and from nearest locations to surveyed profiles in the Tillamook and Netarts subcells (Peterson et al., 1994). 
Table 5. Subcell active-beach profile parameters

\begin{tabular}{|c|c|c|c|c|c|}
\hline Subcell/UTM-N (m) & $\begin{array}{l}\text { Beach width to } \\
\text { MTL (m) }\end{array}$ & $\begin{array}{l}\text { Ave. Beach slope } \\
\text { to MLLW (\%) }\end{array}$ & $\begin{array}{l}\text { Cross-X area above } \\
\text { MHHW }\left(\mathrm{m}^{2}\right)\end{array}$ & $\begin{array}{l}\text { Cross-X area above } \\
\text { MLLW }\left(\mathrm{m}^{2}\right)\end{array}$ & $\begin{array}{l}\text { Beach segment } \\
\text { length }(\mathrm{m})\end{array}$ \\
\hline \multicolumn{6}{|l|}{ Cannon Beach } \\
\hline 5083750 & 250 & 1.6 & 530 & 730 & 2070 \\
\hline 5079700 & 164 & 2.1 & 20 & 220 & 3630 \\
\hline 5077150 & 164 & 2.4 & 30 & 290 & 2830 \\
\hline 5073650 & 180 & 2.1 & 50 & 170 & 3110 \\
\hline 5070000 & 34 & 5.1 & 30 & 110 & 2190 \\
\hline \multicolumn{6}{|l|}{ Tillamook } \\
\hline 5063240 & 140 & 4.2 & 90 & 430 & 2310 \\
\hline 5061530 & 160 & 2.0 & 920 & 1730 & 1430 \\
\hline 5059830 & 100 & 3.8 & 240 & 720 & 5900 \\
\hline 5051000 & 70 & 3.6 & 210 & 530 & 9570 \\
\hline 5041000 & 60 & 5.0 & 160 & 500 & 4620 \\
\hline 5039300 & 50 & 7.1 & 20 & 190 & 2130 \\
\hline \multicolumn{6}{|l|}{ Netarts } \\
\hline 5034400 & 60 & 6.2 & 20 & 110 & 1050 \\
\hline 5032900 & 50 & 5.0 & 0 & 100 & 1570 \\
\hline 5030650 & 100 & 3.8 & 80 & 410 & 1740 \\
\hline 5028820 & 80 & 4.7 & 14 & 490 & 2380 \\
\hline 5025870 & 50 & 5.0 & 20 & 190 & 2750 \\
\hline 5023790 & 30 & 5.0 & 0 & 60 & 1850 \\
\hline
\end{tabular}

Notes: Beach widths (m) are taken from the back-edges of the backshores or bases of foredunes to the beach face intersections with mean tidal level (MTL) during summer months. Beach slopes are the average slope from the back-shore back-edges or bases of the foredunes to the beach intersections with the MLLW tidal elevation. Beach sand cross-section areas $\left(\mathrm{m}^{2}\right)$ for MHHW and MLLW are based on calibrated digitization of areas bounded by 1) profile top surfaces to the sea cliff or mid-slope of the foredune $(<50 \%$ vegetation cover) and to the beach face interception with MLLW, 2) underlying wave-cut platform surfaces, and/or 3) the basal elevation cut-offs at the MHHW or MLLW tidal elevations. Beach segment lengths are measured alongshore using mid-points between profiles or terminal beach deposits near the bounding headlands. The Tillamook Bay tidal inlet ( $500 \mathrm{~m}$ width) is excluded from adjacent profile segment lengths.

Table 6. Analysis of alongshore variability in beach widths

\begin{tabular}{llll}
\hline $\begin{array}{l}\text { Profile location UTM- } \\
\mathrm{N}(\mathrm{m})\end{array}$ & $\begin{array}{l}\text { Aerial photo/video reference site beach } \\
\text { width }(\mathrm{m})\end{array}$ & $\begin{array}{l}\text { Aerial photo/video average beach } \\
\text { width }( \pm 1 \sigma \mathrm{m})\end{array}$ & $\begin{array}{l}\text { Beach width adjustment } \\
\text { factor }\end{array}$ \\
\hline 5083750 & 171 & $172 \pm 7$ & 1.00 \\
5079700 & 137 & $135 \pm 16$ & 0.99 \\
5077150 & 109 & $96 \pm 26$ & 0.89 \\
5073650 & 92 & $86 \pm 23$ & 0.93 \\
5070000 & 44 & $33 \pm 12$ & 0.76 \\
\hline
\end{tabular}

Notes: Reference site beach widths (m) from the back-edge to the beach face intersection with MTL mid-swash zones were measured from aerial photo/video records at each surveyed profile site (Rosenfeld et al., 1991). Aerial photo/video beach widths at $\sim 500 \mathrm{~m}$ alongshore spacing within the profile beach segment are averaged (mean $\pm 1 \sigma$ $\mathrm{m}$ ) and then compared to the reference beach widths to yield an adjustment factors (Peterson et al., 1991; Peterson et al., 1994).

An example of large-scale beach width variability is shown for the Cannon Beach subcell (Table 6). Active-beach widths from aerial photo/videography, taken at mean tide level (time of MTL \pm 1.0 hour), were compiled from $\sim 500 \mathrm{~m}$ spacings within each profile segment (Rosenfeld et al., 1991; Peterson et al., 1991). The aerial photo/video beach width distances were measured from the back-edge to the MTL mid-swash zone. The aerial photo/video beach widths at the surveyed profile locations were compared to values of averaged beach widths within corresponding beach profile segments. The beach width differences between the selected profile locations and the averaged widths from within the corresponding profile segments are represented as adjustment factors, which 
range from 1.00 to 0.76 and average 0.91 in the Cannon Beach subcell. In this study, the reported beach width adjustment factors (Peterson et al., 1994) are used to calibrate measured active-beach sand cross-sectional areas in the Cannon Beach subcell. No such calibrations were made for the Tillamook and Netarts subcells (Doyle, 1996). Based on the adjustment factors calculated for the Cannon Beach subcell, and in three subcells located between the Nestucca and Siuslaw Rivers (Figure 1) (Peterson et al., 1994), we assume a potential $20 \%$ error in the sand cross-sectional areas that are used to represent the active-beach profile segments.

\subsection{Estuary Sand Sinks and Sources}

A field study of the Holocene-fill in Tillamook Bay (Figure 2) was undertaken by Glenn (1978). Seismic lines, drill core samples, and preliminary ${ }^{14} \mathrm{C}$ dates of Holocene deposits were obtained $(0-30 \mathrm{~m}$ depth subsurface) throughout the estuary (Figure 7). Analyses of seismic reflection records from Tillamook Bay (J. Glenn, unpublished data, 1978), as ground-truthed by drill core records were used to map Holocene fill isopach contours ( 0 to $-30 \mathrm{~m}$ MTL) under the current tidal extent of the shallow estuary (Peterson and Darienzo, 1989). Two ancestral tributary valleys (north and south) were flooded by the mid-Holocene transgression ( $\sim-5 \mathrm{ka}$ ) to form a single embayment above the $-10 \mathrm{~m}$ MTL depth contour in late-Holocene time. Selected sediment samples from the recovered drill cores were analyzed for weight percent grain size fractions of gravel $(>2.00 \mathrm{~mm})$, sand $(>0.062$ $\mathrm{mm}$ and $<2.00 \mathrm{~mm})$, and mud $(<0.062 \mathrm{~mm})$. Sand fractions from selected core samples and from endmember sand sources, including modern river deposits and modern beach deposits, were analyzed for hypersthene:augite ratios. Endmember hypersthene:augite ratios from rivers $(0.00)$ and beaches $(0.25)$ were used convert the sand fractions in the estuary drill core samples to percent river and beach sand components. The grain size fraction data and heavy-mineral data from the 0 to $-30 \mathrm{~m}$ depth section in Tillamook Bay are presented in Tillamook Bay Core Data in Supplemental Materials.

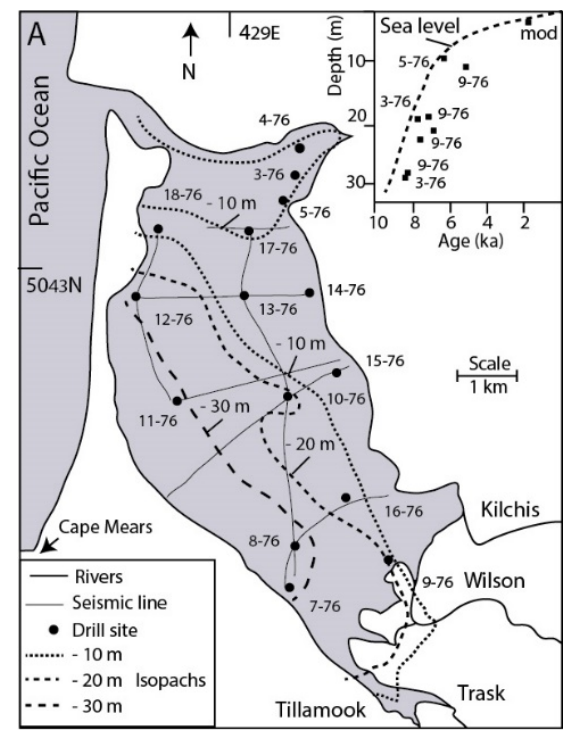

Figure 7. Map of Tillamook Bay

Tillamook Bay map shows the modern shoreline and major rivers (named), seismic lines (thin lines), drill sites (solid circles), and deposit isopachs (dashed lines) at -10, -20, and -30 m MTL, as redrafted from Peterson and Darienzo (1989). Inset shows eustatic sea level curve (dashed line) and dated deposits (solid squares) as redrafted from Glenn (1978). The average modern sediment surface 'mod' in sea level curve plot is shown at MLLW. The Holocene filling of Tillamook Bay generally kept pace with rising sea level, though channel migrations likely reworked some sediments (drill site 9-76) in late-Holocene time. Surplus river sand was transported out of Tillamook Bay to the adjacent littoral cell system (Figure 2).

In this study, estuary sample compositions are used to estimate potential sand sinks in the study area estuaries. Preliminary examinations were performed in the largest estuary Tillamook Bay to establish whether the surface deposits are generally representative of past (late-Holocene) sand sinks in the estuary. Comparisons of drill core sample compositions (Figure 7) are made from different depth sections in Tillamook Bay (Tillamook Bay Core 
Data in Supplemental Materials). The averaged depth section compositions are from 1) the nearest surface samples, which average $-1.7 \mathrm{~m}$ MTL in elevation), 2) the 0 to $-10 \mathrm{~m}$ MTL depth section, and 3) the -10 to $-20 \mathrm{~m}$ MTL depth section (Table 7). The nearest surface samples $(\mathrm{n}=13)$ average $5 \%$ gravel, $71 \%$ sand, and $25 \%$ mud. An averaged hypersthene:augite ratio (0.04) for the sand fractions yields $84 \%$ river sand and $16 \%$ beach sand for the near surface samples. The relative abundances of the sediment size fractions in the deeper intervals, 0 to $-10 \mathrm{~m}$ and -10 to $-20 \mathrm{~m} \mathrm{MTL}$ are essentially the same as in the near surface samples. However, the hypersthene:augite ratio increases slightly with depth, yielding $74 \%$ river sand and $26 \%$ beach sand in the sand fractions from the -10 to 20 m MTL depth interval. A second examination of 'similarity' between surface samples and longer periods of sedimentation in Tillamook Bay included comparisons between 1) averaged compositions from the drill core depth sections (Table 7) and 2) textural compositions of densely sampled surface deposits in Tillamook Bay (Figure 8) (Avolio, 1973). The shallow surface deposits (-1 to - 4 m MTL) collected by Avolio (1973) were compiled for sand and mud fraction weight abundances. Those samples that could be assigned to elevations from contemporary mapped bathymetric contours ( $2 \mathrm{~m}$ depth intervals) from Avolio (1973) totaled 93 samples. The deeper samples $(\mathrm{n}=29)$ from the -2.5 to $-4.0 \mathrm{~m}$ MTL depth interval averaged $85 \%$ sand and $15 \%$ mud. The shallower samples $(\mathrm{n}=64)$ from the -1.5 to $-2.5 \mathrm{~m}$ MTL depth interval averaged $77 \%$ sand and $23 \%$ mud. The shallowest group of samples ( $\mathrm{n}=26$ ) from the $-1.5 \mathrm{~m}$ MTL depth contour ( $0 \mathrm{~m} \mathrm{MLLW)}$ averaged $66 \%$ sand and $33 \%$ mud. The finingupwards trends in Tillamook Bay, as found by Avolio (1973), continue through the intertidal zone where mud dominates above $0.5 \mathrm{~m}$ MTL (Peterson et al., 2000). The averaged relative abundances of sand and mud fractions in the shallow subtidal deposits in Tillamook Bay (Avolio, 1973) are similar to those in the drill core depth sections (Table 7). For surface areas below MLW in Tillamook Bay $\left(16.7 \mathrm{~km}^{2}\right)$ (Table 1) we use an average sand fraction abundance of $70 \%$. For the surface areas between MLW and MTL $\left(8.4 \mathrm{~km}^{2}\right)$ we use the sand fraction abundance mid-point, or $35 \%$. The proportional average of the sand fraction abundance in the combined surface areas below MTL in Tillamook Bay is $\sim 50 \%$ (sand fraction). Based on the $\sim 15 \%$ differences in estimated sand fraction abundances, as presented above, we assume a $20 \%$ potential error in the sand fraction abundance estimate for the combined surface areas below MTL in Tillamook Bay.

Table 7. Summarized drill core sample compositions from Tillamook Bay

\begin{tabular}{llllllll}
\hline $\begin{array}{l}\text { Depth interval }(\mathrm{m} \\
\text { MTL) }\end{array}$ & $\begin{array}{l}\text { Sample } \\
\text { number }\end{array}$ & $\begin{array}{l}\text { Gravel } \\
(\%)\end{array}$ & $\begin{array}{l}\text { Sand } \\
(\%)\end{array}$ & $\begin{array}{l}\text { Mud } \\
(\%)\end{array}$ & $\begin{array}{l}\text { Hypersthene: Augite } \\
\text { ratio }\end{array}$ & $\begin{array}{l}\text { River Sand } \\
(\%)\end{array}$ & $\begin{array}{l}\text { Beach Sand } \\
(\%)\end{array}$ \\
\hline Near surf. & 13 & 5 & 71 & 25 & 0.04 & 84 & 16 \\
0 to $-10 \mathrm{~m}$ & 30 & 2 & 71 & 23 & 0.05 & 81 & 19 \\
-10 to $-20 \mathrm{~m}$ & 20 & 4 & 69 & 31 & 0.07 & 74 & 26 \\
\hline
\end{tabular}

Notes: Nearest surface samples (-0.5 to $-4.0 \mathrm{~m}$ MTL) average $-1.7 \mathrm{~m}$ mean tide level (MTL).
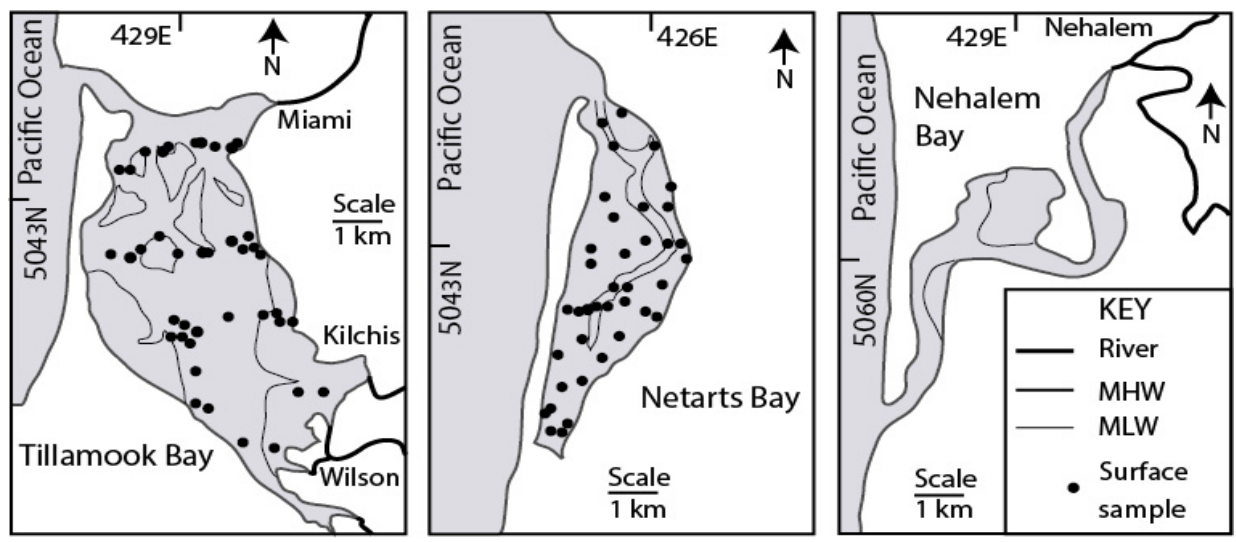

Figure 8. Maps of Tillamook Bay, Netarts Bay, and Nehalem Bay

Estuary maps show river confluences, tidal levels, MHW and MLW (lines), and surface sediment sample sites (solid circles) from Tillamook Bay (Avolio, 1973) and Netarts Bay (Hunger, 1996). No wide-spread surface sediment textural data is available for Nehalem Bay.

By comparison to the sand size fraction estimates in Tillamook Bay, much smaller difference (3\%) occur between 
estimated averaged river- and beach- sand components in the sand size fractions from shallow depths $(0$ to- $10 \mathrm{~m}$ MTL) in the estuary (Table 7). The averaged river and beach sand source compositions of the sand fractions in the combined surface areas below MTL, respectively, are taken to be $80 \%$ (river) and $20 \%$ (beach). Based on the small ranges in averaged hypersthene:augite ratios found in Tillamook Bay, a relatively small potential error (10\%) is assumed for the averaged river and beach sand contributions to most-recent sand fraction fill in Tillamook Bay. Although Tillamook Bay has a moderate $\mathrm{Hr}$ ratio=36 (Table 1), the dominant river sand supply throughout the estuary suggests some river sand bypassing to the littoral zone, possibly assisted by estuary wind-wave resuspension, as occurs in the very-large Columbia River estuary (Peterson et al., 2014).

The sand source contributions in the Netarts and Nehalem Bays are straightforward. The sand fractions in the marine-dominated Netarts Bay (Hr> 100) are entirely beach sand (100\%), as no rivers enter Netarts Bay (Figure 8 and Table 1). In the fluvially-dominated Nehalem Bay $(\mathrm{Hr}=10)$, lithic-rich river sand and fine gravel extend to the lowest estuarine reaches $(\sim 1 \mathrm{~km}$ from the mouth). An averaged source composition of the sand fraction in Nehalem Bay ( $\sim 10 \mathrm{~km}$ length) is therefore assumed to be $\sim 90 \%$ river sand and $\sim 10 \%$ beach sand. Much of the current river bedload delivered to Nehalem Bay is assumed to bypass through the fluvially-dominated estuary to reach the littoral zone. Sand fraction abundances in Netarts Bay are provided by Hunger (1996). Hunger analyzed 73 samples from the lower intertidal flats and the small subtidal channel in Netarts Bay, resulting in 64 sites dominated by fine -to- medium size sand and nine sites dominated by mud. For this study, the combined surface areas below MTL in Netarts Bay are assigned average sand- and mud-fraction abundances, respectively, of $\sim 90 \%$ and $\sim 10 \%$. Mud and tidal marsh dominate the surface areas above $0.5 \mathrm{~m}$ MTL in Nehalem Bay (Eilers, 1974), but no sediment size class data are available for the lower-intertidal and subtidal surface areas in Nehalem Bay. For this study, we use the total averaged value of sediment size class fractions in Tillamook Bay to assign a conservative value of $50 \%$ sand size fraction for the combined surface areas below MTL in Nehalem Bay.

\subsection{Inner-Shelf Profiles}

The inner-shelf bathymetries in the study area subcells are characterized by representative across-shelf profiles (Figure 9). Inner-shelf gradients are summarized for shoreline distances to $30 \mathrm{~m}$ and $50 \mathrm{~m}$ offshore water depths in the Cannon Beach, Tillamook, and Netarts subcells. Inner-shelf gradients are relatively uniform, both within and between the three subcells (Table 8), with averaged gradients to the 30 and $50 \mathrm{~m}$ water depths, respectively, of $1.2 \pm 0.1 \% 1 \sigma$ and $1.0 \pm 0.11 \sigma(\mathrm{n}=10)$. For this study the seaward limits of the innermost-shelf and the innershelf, respectively, are taken to be at the $30 \mathrm{~m}$ and 50 water depths. Most important to this study, the across-shelf gradients in the three-subcell study area (1.0-1.2 \%) are well within the range $(>0.40 \%)$ that permitted seaward transport and deposition of Columbia River-derived littoral sand in the inner-shelf during the Holocene marine transgression in the adjacent CRLC system (Figure 1) (Peterson et al., In Press). Shallower gradients $(<0.35 \%)$ lead to shoreward transport and stripping of pre-transgressive deposits, which occurred in the northernmost subcell (north of Grays Harbor) in the CRLC system (Figure 1).

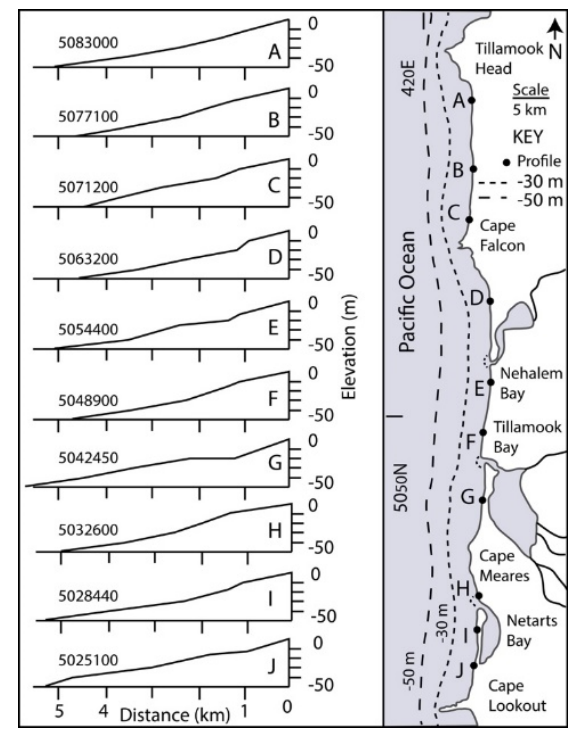

Figure 9. Inner-shelf profiles and profile locations 
Map of the three-subcell study area shows offshore (inner-shelf) bathymetric contours (dashed lines) at $-30 \mathrm{~m}$ and $-50 \mathrm{~m}$ elevations, onshore dividing headlands (named), and inshore tidal inlets (named estuaries), with very-small ebb tide deltas (dotted lines). The locations of across-shelf profiles (solid circles with letters A-J) correspond to plotted profiles that include UTM-N coordinates (Table 8).

Table 8. Inner-shelf profiles

\begin{tabular}{llllllll}
\hline Settings & UTM-N $(\mathrm{m})$ & Depth el. $(\mathrm{m})$ & Distance $(\mathrm{m})$ & Gradient (\%) & Depth el. $(\mathrm{m})$ & Distance $(\mathrm{m})$ & Gradient $(\%)$ \\
\hline Subcell beaches & & & & & & & \\
Cannon Beach & 5083000 & -30 & 2480 & 1.2 & -50 & 5110 & 1.0 \\
& 5077100 & -30 & 2410 & 1.2 & -50 & 4790 & 1.0 \\
& 5071200 & -30 & 2790 & 1.1 & -50 & 4490 & 1.1 \\
Tillamook & 5063200 & -30 & 2230 & 1.3 & -50 & 4690 & 1.0 \\
& 5054400 & -30 & 2470 & 1.2 & -50 & 5110 & 1.0 \\
& 5048900 & -30 & 2240 & 1.3 & -50 & 4690 & 1.1 \\
& 5042500 & -30 & 3400 & 0.9 & -50 & 5960 & 0.8 \\
Netarts & 5032600 & -30 & 2450 & 1.2 & -50 & 5060 & 1.0 \\
& 5028440 & -30 & 2360 & 1.3 & -50 & 5380 & 0.9 \\
Headlands & 5025100 & -30 & 3020 & 1.0 & -50 & 5300 & 0.9 \\
Tillamook Head & 5088500 & -30 & 890 & 3.4 & -50 & 2560 & 1.9 \\
Cape Falcon & 5068700 & -30 & 1090 & 2.7 & -50 & 2990 & 1.7 \\
Cape Meares & 5037400 & -30 & 1950 & 1.5 & -50 & 3830 & 1.3 \\
Cape Lookout & 5020900 & -30 & 420 & 7.1 & -50 & 1430 & 3.5 \\
Ebb tide deltas & & & & & & 5230 \\
Nehalem & 5056300 & -30 & 2550 & 1.2 & -50 & -50 & 0.9 \\
Tillamook & 5046500 & -30 & 2540 & 1.2 & -50 & 5130 & 1.0 \\
Netarts & 5032000 & -30 & 2760 & 1.1 & -50 & 1.0
\end{tabular}

Notes: Three across-shelf profiles were compiled, over $\sim 200 \mathrm{~m}$ alongshore distances, to yield average gradients for each profile location, which corresponds to the central profile position (UTM-Northings in meters). Water depth or elevation (el. m), east-west distance (m), and profile gradient (\%) are shown for the 30 and $50 \mathrm{~m}$ water depths. Bathymetric data are from Google Earth (2020).

Across-shelf profiles that are located offshore of the headlands that divide the three subcells in the study area (Figure 9) are evaluated for gradients to the $30 \mathrm{~m}$ and $50 \mathrm{~m}$ water depths (Table 8). Innermost-shelf gradients, extending across the innermost-shelf ( $0-30 \mathrm{~m}$ water depth), are as follows: Tillamook Head (3.4\%), Cape Falcon $(2.7 \%)$, Cape Meares $(1.5 \%)$ and Cape Lookout $(7.1 \%)$. The high gradients correspond to narrowing of the innermost-shelf between the headland's seaward-most points and the $30 \mathrm{~m}$ water depth contour, ranging in distance from as much as 2,000 m (Cape Meares) to as little as $500 \mathrm{~m}$ (Cape Lookout). The combinations of opposing shoreline angles to longshore currents and the reduced widths of innermost-shelf transport conduits at the headlands interrupt the slight net-northward littoral transport in the study region (Figure 2). For example, the south end of the Netarts subcell, bounded to the south by Cape Lookout, has yet to fully recover from prolonged shoreline retreat that was underway in the early 1980s (Minor and Peterson, 2016). Across-shelf profiles are also presented for the very-small ebb tide deltas that are developed offshore of the Nehalem, Tillamook, and Netarts estuary tidal inlets (Figure 9). The across-shelf gradients to the $30 \mathrm{~m}$ water depth offshore of the tidal inlets, show no significant variations from adjacent beach profiles in the three subcells (Table 8). The very-small ebb tide deltas formed at the mouths of the Nehalem, Tillamook, and Netarts estuaries are unlikely to have blocked longshore transport in the inner-shelf or to have jetted littoral sand across the inner-shelf to reach the outer reaches of the inner-shelf between 30 and $50 \mathrm{~m}$ water depths.

\section{Discussion}

\subsection{Beach Sand Sources}

Metamorphic amphiboles in the innermost mid-shelf area (50-100 $\mathrm{m}$ water depth) of the study region reflect northward dispersal during late-Pleistocene time of marine-low stand conditions and mid-shelf emergence (Figure 10) (Scheidegger et al., 1971). Onshore records of that northward dispersal are shown by the presence of 
metamorphic amphiboles in the late-Pleistocene dune sheet deposits (Table 3). The apparent hypersthene dispersal, which occurred just north of the Umpqua River source, crosses between the inner- and mid-shelf areas. However, the northward dispersal of hypersthene must have extended further north to supply the small abundances of hypersthene in the northernmost paleo-dune sheets. The youngest paleo-dune deposit with elevated hypersthene is dated to $\sim 11 \mathrm{ka}$, indicating very-late northward sand dispersal that possibly extended into Holocene time. Mostimportant to this study is the very-clear extent of augite-rich sand that is restricted to the inner-shelf along most of the northern Oregon coast. Such an augite-rich sand supply does not reflect either the northward along-shelf dispersal of metamorphic amphiboles or hypersthene, but rather a seaward (offshore transport) dispersal from the local North Coast Range rivers.

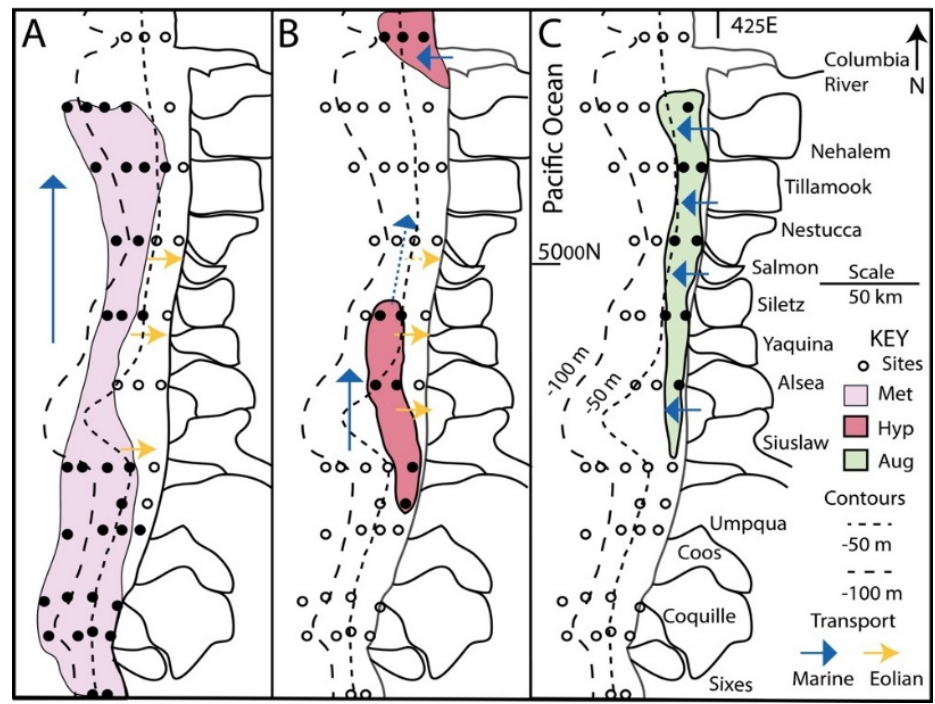

Figure 10. Maps of heavy-mineral tracer dispersals on the continental shelf

Heavy-mineral tracers include metamorphic amphiboles (Met), hypersthene (Hyp), and augite (Aug). Metamorphic amphiboles include blue-green hornblende, actinolite, and tremolite. Heavy-mineral patterns are redrafted from factor loadings, as reported by Scheidegger et al. (1971). Interpreted transport mechanisms (marine and eolian) are based on heavy-mineral tracers in late-Pleistocene dune sheet deposits, modern beaches, and modern rivers (Table 3 and Figure 3). Part A, the northward dispersal of metamorphic amphiboles (Met) along the mid-shelf by marine processes and landward transport across the emerged inner-shelf by eolian processes occurred in late-Pleistocene time. Part B, hypersthene (Hyp) was delivered to the shelf by large antecedent rivers, including the Umpqua River in the central region and the Columbia River in the northern region, during latest-Pleistocene and Holocene times. Part C, augite (Aug) was delivered from the North Coast Range rivers to the three-subcells study area beaches, where marine processes dispersed the augite-enriched littoral sand seaward across the innershelf in latest-Holocene time.

The reversal in across-shelf sand transport from landward directed in late-Pleistocene and early- to mid-Holocene time to seaward directed in latest-Holocene time is demonstrated by the following sequences. Metamorphic amphibole- and hypersthene-enriched sands covered the inner-shelf during marine low-stand conditions of latePleistocene and early- to mid-Holocene times (Figure 10). During slowed SLR in late-Holocene time, the innershelf sands were scoured to maximum wave base and some estuaries became over-filled with the abundant river sand supply (Table 7). During the continued modest rates of SLR in latest-Holocene time, the scoured sea bottom fell below maximum wave base, and estuaries delivered river sand to adjacent beaches. The previously eroded offshore (inner-shelf) deposits were then covered by augite-enriched littoral sand that was transported offshore from the beaches. The net offshore (seaward) transport supplied littoral sand to the recently increased accommodation spaces in the inner-shelf. For example, the augite-rich littoral sand extends across the inner-shelf to water depths of $50 \mathrm{~m}$ in the vicinity of the three-subcell study area, as shown in Figure 10. Though the rate of inner-shelf accommodation space filling is not constrained in the three-subcell study area, such rates are established in the adjacent CRLC system (Figure 1). The rate of filling there kept pace with latest-Holocene sea level rise $\left(1.0 \mathrm{~m} \mathrm{ka}^{-1}\right)$ across the innermost-shelf to water depths of at least $30 \mathrm{~m}$ (Peterson et al., In Press). For the purposes of this study, it is assumed that seaward transport and offshore deposition of littoral sand in the threesubcells study area occurred in response to increasing accommodation space in the innermost-shelf during latest- 
Holocene time. The net loss of sand from the study region beaches during latest-Holocene time (Hart and Peterson, 2007; Peterson et al., 2019) was due, not only to the filling of littoral sand accommodation spaces in the small estuaries, but more-importantly it was lost to the much larger areas of available accommodation space in the innershelf was gradually submerging by relative SLR.

Another important finding that is shown by the offshore transport of augite-enriched littoral sand in the threesubcell study area (Figure 10), is that the seaward transport was not assisted by major river flooding, abundant sand supply, or large ebb tide deltas. Those conditions and features, which do occur in the adjacent CRLC system (Figure 1), do not occur in the three-subcell study area (Figure 9). By analogy, the offshore transports of littoral sand in the CRLC system (Peterson et al., In Press), need not be largely influenced by the Columbia River or the flood tide deltas of the Columbia River, Willapa Bay, and Grays Harbor estuaries. Rather, the offshore transports of littoral sand across and along the inner-shelf in latest-Holocene time, in both the CRLC and in the three-subcell study area, are apparently forced by storm wave dynamics and geostrophic- and downwelling-currents, as previously proposed by Sternberg and Larsen (1976), Sternberg (1986), and Katchel and Smith (1986) for the CRLC system.

\subsection{Beach Sand Erosion Estimates}

Averaged beach sand compositions in the three-subcell study area indicate endmember contributions from local rivers $(\sim 75 \%)$ and paleo-shelf deposits ( $25 \%)$ (Table 3$)$. The minor sand contributions from the marine side could be supplied by 1) remnant nearshore deposits derived from the mid-Holocene marine transgression, 2) eroding paleo-dune deposits in retreating sea cliffs (Peterson et al., 2009) or 3) northward longshore transport in the inner-shelf (Figure 10). In any case, the net beach retreat at the south ends of Netarts and Cannon Beach subcells, which lack direct river sand supply, demonstrate that the marine-side sand supply has not kept pace with net beach sand loss. Sea cliffs in the Cannon Beach subcell contain Tertiary mudstones, intruded basalts, and latePleistocene lagoon-mud deposits (Mulder, 1992), none of which delivered significant quartz-rich sand to the littoral sand deposits in that subcell. A small sand ramp in the northern end of the Netarts subcell (Peterson et al., 2019) did deliver some sand to the Netarts subcell, but only as a consequence of progressive beach erosion which undermined the sand ramp. By comparison, multiple North Coast Range rivers delivered substantial volumes of river sand to the Tillamook subcell via the Nehalem and Tillamook estuaries in late-Holocene time (Figure 8). To evaluate whether those two estuaries could serve as net sources or sinks of sand to the Tillamook littoral system, following potential SLR of $0.5 \mathrm{~m}$ or $1.0 \mathrm{~m}$ during the next century (100 years), the current river bedload supplies (Table 1) are compared to estimated increases in river-sand accommodation space volume in the two estuaries (Table 11). The reported estuarine surface areas below MTL (Table 1) are multiplied by either 0.5 or $1.0 \mathrm{~m}$ of sand vertical accretion, as well as by the proportions of sand fractions (percent by surface areas) and by the relative proportions of river versus littoral sand components (percent by surface areas) to yield potential accommodation spaces for the river and beach sand components. The annual river bedload supply rates in the Nehalem and Tillamook estuaries (Table 1) are multiplied by 100 years to establish the balance between river sand volume supply, river sand volume accumulation, and river sand volume bypassing to the littoral zone in the two estuaries. Similar approaches are used to calculate the potential sinks of littoral sand, by volume in the Nehalem, Tillamook, and Netarts Bays, following SLR of either $0.5 \mathrm{~m}$ or $1.0 \mathrm{~m}$, as shown in Table 11. For example, the Nehalem estuary is estimated to produce a very-small net supply of river sand $\left(0.3 \times 10^{6} \mathrm{~m}^{3}\right)$ to the Tillamook subcell beaches, and to possibly accumulate a similar small volume of beach sand $\left(0.3 \times 10^{6} \mathrm{~m}^{3}\right)$ from the subcell beaches, following a $1.0 \mathrm{~m}$ SLR over a period of 100 years. Due to the large river sand accommodation space in Tillamook Bay, it would not serve as a source of new river sand to the adjacent subcell beaches, but it could serve as a sink for an appreciable volume of beach sand $\left(2.3 \times 10^{6} \mathrm{~m}^{3}\right)$ following a $1.0 \mathrm{~m}$ SLR. Under the $1.0 \mathrm{~m}$ SLR scenario, the small Netarts Bay could accumulate a substantial beach sand volume $\left(5.7 \times 10^{6} \mathrm{~m}^{3}\right)$ from the adjacent subcell beaches, as based on its potential for beach sand accommodation. One half of these volumes are predicted for the smaller $0.5 \mathrm{~m} \mathrm{SLR}$, relative to the $1.0 \mathrm{~m} \mathrm{SLR}$, in the three estuaries.

Late-Holocene sand ramps developed at the north ends of all three subcells in the study area (Figure 2), demonstrate a slight net-northward longshore transport over century to millennial time scales. However, modern contiguous beach deposits occur along $\sim 90 \%$ of each subcell's length (Table 5), which show that seasonallyreversing wave directions control the longshore sand distributions in each subcell. Net-longshore transport and potential headland bypassing are considered to be negligible at the one century time scale, relative to the potential offshore displacements of beach sand that are expected to follow near-future SLR. For these reasons, the seaward losses of beach sand from the subcells are apportioned to corresponding offshore areas within (between) bounding headlands. The potential offshore areas of littoral sand displacement (Figure 11) are bounded by 1) the dividing headlands, 2) outer-limits of the innermost-shelf (30 m water depth), and 3) a transition zone (1,000 m) between 
beach erosion and inner-shelf net accumulation, as proportionally-diagramed by Bruun (1962). The $30 \mathrm{~m}$ water depth represents the offshore extent to which net-accretion of littoral sand has kept pace with latest-Holocene SLR $\left(1.0 \mathrm{~m} \mathrm{ka}^{-1}\right)$ in the adjacent CRLC system (Peterson et al., In Press). Such fill rates in the CRLC innermost-shelf have continued up to present time, within error bounds of ${ }^{14} \mathrm{C}$ dating. Because the rates of offshore sand displacement have not been directly measured in the three-subcelll study area (Figure 9), two rates of vertical accretion are assumed for potential sea level rise during the next century, including $0.5 \mathrm{~m}$ and $1.0 \mathrm{~m}$ per $100 \mathrm{yr}$. Multiplications of the digitized offshore submarine accumulation areas by $0.5 \mathrm{~m}$ of vertical sand accretion yield the following offshore littoral sand accommodation space volumes: Cannon Beach subcell $\left(13.7 \times 10^{6} \mathrm{~m}^{3}\right)$, Tillamook subcell $\left(22.9 \times 10^{6} \mathrm{~m}^{3}\right)$, and Netarts subcell $\left(12.4 \times 10^{6} \mathrm{~m}^{3}\right)$. Multiplications of the digitized submarine accumulation areas by $1.0 \mathrm{~m}$ of vertical sand accretion yield the following offshore littoral sand accommodation space volumes: Cannon Beach subcell $\left(27.4 \times 10^{6} \mathrm{~m}^{3}\right)$, Tillamook subcell $\left(45.9 \times 10^{6} \mathrm{~m}^{3}\right)$, and Netarts subcell $\left(24.8 \times 10^{6} \mathrm{~m}^{3}\right)$. These are the potential volumes that could be filled by littoral sand displacement to the offshore accommodation spaces following predicted near-future SLR.

Table 11. Estuary sources and sinks of sand following 0.5 and $1.0 \mathrm{~m}$ sea level rise over a 100 -year period

\begin{tabular}{lllll}
\hline $\begin{array}{l}\text { Sea Level Rise } \\
(\mathrm{SLR}) / \text { Estuary }\end{array}$ & $\begin{array}{l}\text { River sand supply } \\
\left(\mathrm{x} 10^{6} \mathrm{~m}^{3}\right) \text { over } 100 \mathrm{yr}\end{array}$ & $\begin{array}{l}\text { River sand accommodation } \\
\text { space }\left(\mathrm{x} 10^{6} \mathrm{~m}^{3}\right)\end{array}$ & $\begin{array}{l}\text { Littoral sand accommodation } \\
\text { space }\left(\mathrm{x} 10^{6} \mathrm{~m}^{3}\right)\end{array}$ & $\begin{array}{l}\text { Net sand supply }(+) \text { sink } \\
(-) \text { to beaches }\left(\mathrm{x} 10^{6} \mathrm{~m}^{3}\right)\end{array}$ \\
\hline SLR $(0.5 \mathrm{~m})$ & & & 0.1 & +0.1 \\
Nehalem Bay & 3.3 & 1.5 & 1.1 & -1.1 \\
Tillamook Bay & 2.7 & 4.5 & 2.8 & -2.8 \\
Netarts Bay & 0 & 0 & & +0.3 \\
SLR (1.0 m) & & & 0.3 & -2.3 \\
Nehalem Bay & 3.3 & 3.0 & 2.3 & -5.7 \\
Tillamook Bay & 2.7 & 9.0 & 5.7 & +3 \\
Netarts Bay & 0 & 0 & & \\
\hline
\end{tabular}

Notes: River sand supply is normalized to 100 years of annual bedload production are from Table 1. River and beach sand accumulations are based on the estuary surface areas below MTL and the estimated average components of the sand fractions and the ratios of river -to- beach sand supply to those sand fractions in each estuary (Tables 1 and 7). Estimated potential errors for the sand fraction accumulations in the three estuaries could be $\pm 20 \%$, but volumes are rounded to $0.1 \times 10^{6} \mathrm{~m}^{3}$.
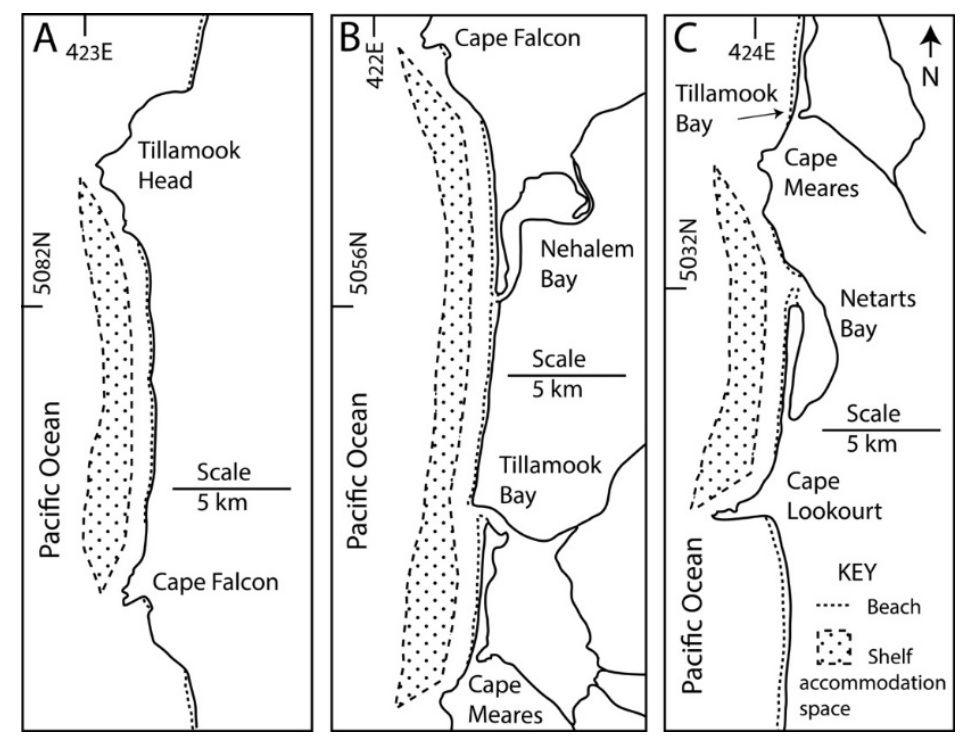

Figure 11. Maps of predicted innermost-shelf accommodation spaces

Maps show predicted future accommodation spaces (dotted areas) in the innermost-shelf located offshore of the Cannon Beach subcell (Part A), the Tillamook subcell (Part B), and the Netarts subcell (Part C). The innermost- 
shelf accommodation space areas are bounded by 1) the subcell dividing headlands, 2) the $30 \mathrm{~m}$ water depth contour, and 3$)$ an offshore distance of $1.0 \mathrm{~km}$ from adjacent beaches $(0 \mathrm{~m} \mathrm{MTL})$. The digitized surface areas, multiplied by $0.5 \mathrm{~m}$ sand sedimentation, are as follows: Cannon Beach subell $\left(13.7 \times 10^{6} \mathrm{~m}^{3}\right)$, Tillamook subcell $\left(22.9 \times 10^{6} \mathrm{~m}^{3}\right)$, and Netarts subcell $\left(12.4 \times 10^{6} \mathrm{~m}^{3}\right)$. The digitized surface areas, multiplied by $1.0 \mathrm{~m}$ sand sedimentation, are as follows: Cannon Beach subell $\left(27.4 \times 10^{6} \mathrm{~m}^{3}\right)$, Tillamook subcell $\left(45.9 \times 10^{6} \mathrm{~m}^{3}\right)$, and Netarts subcell $\left(24.8 \times 10^{6} \mathrm{~m}^{3}\right)$.

Comparisons of the existing beach sand volumes, innermost-shelf accommodation space volumes, and estuary source or sink volumes of beach sand for each of the study area subcells are shown in Table 12. These comparisons are used to make estimates of the deficits to the beach sand supplies following near-future SLR of 0.5 or $1.0 \mathrm{~m}$. For these analyses beach erosion is only taken to the MLLW elevation datum. However larger SLR $(>1.0 \mathrm{~m})$ could include deeper excavations in the uppermost shoreface (Peterson et al., In Press), where not restricted by shallow bedrock in wave-cut platforms. The estimated deficits to the beach sand supplies, beyond the existing active-beach sand volumes, for $0.5 \mathrm{~m}$ SLR are as follows: Cannon Beach subcell $\left(9.9 \times 10^{6} \mathrm{~m}^{3}\right)$, Tillamook subcell $\left(8.5 \times 10^{6} \mathrm{~m}^{3}\right)$, and Netarts subcell $\left(12.4 \times 10^{6} \mathrm{~m}^{3}\right)$. The estimated deficits to the beach sand supplies for $1.0 \mathrm{~m}$ SLR are as follows: Cannon Beach subcell $\left(23.4 \times 10^{6} \mathrm{~m}^{3}\right)$, Tillamook subcell $\left(32.7 \times 10^{6} \mathrm{~m}^{3}\right)$, and Netarts subcell $\left(27.7 \times 10^{6} \mathrm{~m}^{3}\right)$. Under either of the assumed conditions of $0.5 \mathrm{~m}$ or $1.0 \mathrm{~m}$ SLR and associated $0.5-1.0 \mathrm{~m}$ of vertical filling of offshore and estuary littoral sand accommodation spaces, the estimated impacts of net beach erosion are catastrophic. The potential losses of beach sand, largely due to offshore sand displacements, from $0.5 \mathrm{~m}$ of SLR exceed the existing active-beach sand reserves by about one half in the Tillamook subcell and by about four times in the Netarts subcell. The littoral sand deficits are twice as large for the $1.0 \mathrm{~m}$ SLR scenarios in the two subcells. The $0.5 \mathrm{~m}$ SLR beach sand deficits could also apply to a $1.0 \mathrm{~m}$ SLR but with only one half the accommodation space filling to $0.5 \mathrm{~m}$ sand thickness over the 100-year period. The use of two scenarios of accommodation space filling with $0.5 \mathrm{~m}$ and $1.0 \mathrm{~m}$ of vertical accretion, are provided here to compensate for uncertainties about rates of sedimentation in the innermost-shelf and estuaries, following future SLR. Given the uncertainties listed in Tables 11 and 12, the most conservative conditions of littoral system response to near-future SLR lead to a complete loss of active-beach deposits above MLLW throughout the study area. In the sea cliff-backed beaches, such a catastrophic sand loss would resemble the recent erosional conditions of a narrow cobble berm overlying an exposed wave-cut platform, as shown in Figure 4B. In the barrier- and dune-backed shorelines, such as those shown in Figure 4A, sand erosion down to the MLLW elevation at the seaward slope of the modern foredunes could lead to further soft shoreline retreat, as evaluated below.

Table 12. Beach sand volumes, accommodation spaces, and beach sand deficits from SLR

\begin{tabular}{llllll}
\hline $\begin{array}{l}\text { Sea level Rise } \\
(\mathrm{SLR}) / \text { Subcell }\end{array}$ & $\begin{array}{l}\text { Subcell beach sand } \\
\text { volume above } \\
\text { MHHW }\left(\mathrm{x} 10^{6} \mathrm{~m}^{3}\right)\end{array}$ & $\begin{array}{l}\text { Subcell beach sand } \\
\text { volume above MLLW } \\
\left(\mathrm{x} 10^{6} \mathrm{~m}^{3}\right)\end{array}$ & $\begin{array}{l}\text { Innermost-shelf } \\
\text { accommodation space } \\
\text { volume }\left(\mathrm{x} 10^{6} \mathrm{~m}^{3}\right)\end{array}$ & $\begin{array}{l}\text { Estuary source } \\
(+) \text { sink }(-)\left(\mathrm{x} 10^{6}\right. \\
\left.\mathrm{m}^{3}\right)\end{array}$ & $\begin{array}{l}\text { Beach sand } \\
\text { deficit }\left(\mathrm{x} 10^{6}\right. \\
\left.\mathrm{m}^{3}\right)\end{array}$ \\
\hline SLR $(0.5 \mathrm{~m})$ & & & & & \\
Cannon Beach & 1.4 & 3.7 & 13.7 & +0.1 & 9.9 \\
Tillamook & 5.7 & 15.5 & 22.9 & -1.1 & 8.5 \\
Netarts & 0.3 & 2.8 & 12.4 & -2.8 & 12.4 \\
SLR $(1.0 \mathrm{~m})$ & & & & & 23.4 \\
Cannon Beach & 1.4 & 3.7 & 27.4 & -0.3 & 32.7 \\
Tillamook & 5.7 & 15.5 & 45.9 & -5.7 & 27.7 \\
Netarts & 0.3 & 2.8 & 24.8 & -5.7 \\
\hline
\end{tabular}

Notes: Existing beach sand volumes $\left(\mathrm{x}^{6} 0^{6} \mathrm{~m}^{3}\right)$ above mean higher high water (MLLW) and mean lower low water (MLLW) are from the sums of beach profile segment cross-sectional areas multiplied by corresponding lengths in each subcell (Table 5). Innermost-shelf accommodation spaces, following either $0.5 \mathrm{~m}$ or $1.0 \mathrm{~m}$ sea level rise (SLR) are from Figure 11. The predicted increases in submarine accommodation space volumes are differenced from available active-beach sand volumes, and estuarine sand sources/sinks to yield deficits in beach (littoral) sand reserves for the 0.5 and 1.0 SLR, or vertical sand accretion scenarios. Subcell beach sand volume estimates are reported here to 0.1 million cubic meters resolution, though maximum potential errors of $(20 \%)$ are estimated from measured beach width variabilities in the Cannon Beach subcell. The surface areas of innermost-shelf accommodation space are probably of a similar uncertainty, but much greater uncertainties are associated with the assumed fill rates of submarine accommodations spaces (offshore and inshore). Two different fill rate scenarios of 0.5 and $1.0 \mathrm{~m}$ vertical sand accumulation in 100 years are used here to address the uncertainties of beach sand deficits in the three subcells. 
The beach sand deficit volumes presented in Table 12 are further utilized here to predict retreat distances of the soft sand deposits in barrier spits and foredune plains that back the current active-beaches in the Tillamook and Netarts subcells (Table 4 and Figure 8). Back-beach barrier and beach/dune plain volumes above MLLW or $0 \mathrm{~m}$ NAVD88 are established from recent (2009) coastal lidar surveys (DOGAMI, 2019). Some built structures in the Rockaway area (Figure 2) are removed from the bare-ground lidar elevations using a clipping function. The use of a zero-slope basal boundary at $0 \mathrm{~m}$ NAVD8 8 for the back-beach shoreline retreat is assumed to provide an average depth of truncation, taking into account for a seaward dipping gradient and a concave-up landward scarp in the shorter retreat profiles (Figure 12). Estimated retreat distances needed to equal the estimated beach sand deficits from Table 12 are presented in Table 13. The averaged back-beach retreat distances for 0.5 and $1.0 \mathrm{~m}$ of SLR, or assumed accommodation space vertical filling scenarios, in the Tillamook Bay subcell, respectively, are predicted to be $50 \mathrm{~m}$ and $180 \mathrm{~m}$. These distances are added to the eroded active-beach widths in the Tillamook subcell (Table 5) to yield total predicted retreat distances of $150 \mathrm{~m}$ and $280 \mathrm{~m}$, respectively, for the 0.5 and $1.0 \mathrm{~m}$ SLR scenarios. The averaged retreat distances for 0.5 and $1.0 \mathrm{~m}$ of SLR, or accommodation space vertical filling, in the southern half of the Netarts subcell (Netarts Bay spit), respectively, are predicted to be $320 \mathrm{~m}$ and $720 \mathrm{~m}$. Total retreat distances in the southern one half of the Netarts subcell are predicted to be $370 \mathrm{~m}$ and $770 \mathrm{~m}$, respectively, for the 0.5 and $1.0 \mathrm{~m}$ SLR scenarios. The very-large retreat distances in the Netarts Bay spit, would likely result in beach truncation well below the MLLW cut-off, warranting additional geometric considerations for uppermost-shoreface sand displacements (Peterson et al., In Press).

There are several types of uncertainties associated with predicting barrier/dune deposit retreat, including 1) the ranges in beach sand deficits (Table 12), 2) the depths of basal beach erosion (Figure 5), and 3) the averaged volumes of existing beach sand (Table 5), but also 4) the extents of future shoreline hardening by rip-rap revetments and concrete seawalls. For example, at least $250 \mathrm{~m}$ of total beach retreat distance in the Rockaway area of the Tillamook subcell (Table 13) would eliminate several hundred residences/commercial buildings and a State highway. Shoreline hardening, which has been underway in the Rockaway area during the last several decades (see Background section 2.3), would widely expand to other developed shorelines in the study area, following accelerated beach sand loss and soft-sand shoreline erosion. The inevitable hardening of such soft shorelines will further reduce the public ownership of, and access to, sandy beaches in those impacted areas following potential future accelerated SLR.

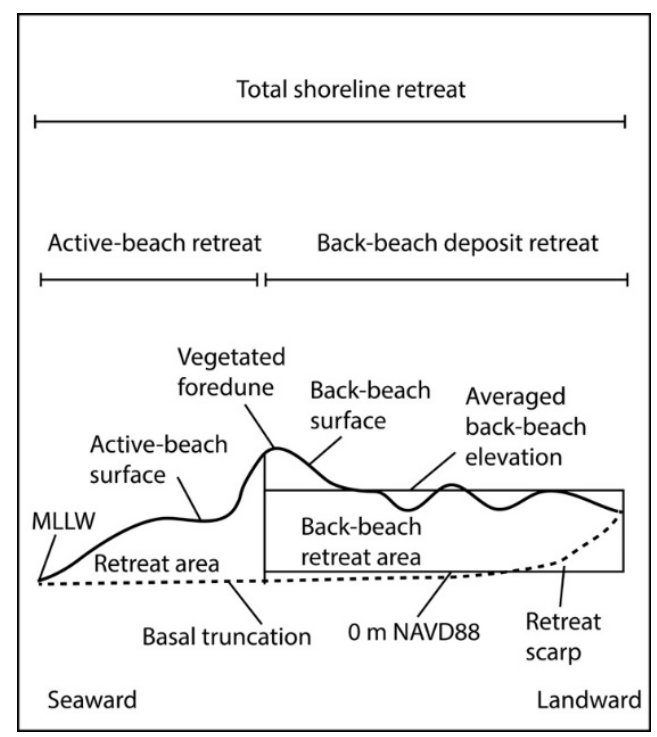

Figure 12. Diagram of predicted averaged retreat volumes and distances for back-beach barrier and dune deposits

Shoreline retreat volumes and distances are evaluated for back-beach shorelines that are developed against barrier spits, sand ridges, and/or beach/dune plains, referred to here as 'soft shorelines'. For this article basal truncation is simplified to the MLLW or $0 \mathrm{~m}$ NAVD88 elevation datum. The back beach mean elevations are taken from lidar DEMs (2009) (DOGAMI, 2019) for the area of predicted sand volume retreat to balance the estimated deficit needed to fill the increased submarine accommodation space (offshore and inshore) following future SLR. 
Table 13. Estimated retreat distances for back-beach dune and barrier spit deposits above MLLW in the Tillamook and Netarts subcells following potential future SLR

\begin{tabular}{|c|c|c|c|c|c|c|}
\hline $\begin{array}{l}\text { Sea Level } \\
\text { Rise/ Subcell }\end{array}$ & $\begin{array}{l}\text { Shoreline } \\
\text { segments UTM-N } \\
\text { (m) }\end{array}$ & $\begin{array}{l}\text { Shoreline } \\
\text { length }(\mathrm{m})\end{array}$ & $\begin{array}{l}\text { Average back-beach } \\
\text { thickness (m) }\end{array}$ & $\begin{array}{l}\text { Deficit volume } \\
\left(\times 10^{6} \mathrm{~m}^{3}\right)\end{array}$ & $\begin{array}{l}\text { Back-beach retreat } \\
\text { distance }(\mathrm{m})\end{array}$ & $\begin{array}{l}\text { Total retreat } \\
\text { distance }(\mathrm{m})\end{array}$ \\
\hline \multicolumn{7}{|l|}{$\operatorname{SLR}(0.5 \mathrm{~m})$} \\
\hline Tillamook & $\begin{array}{l}5063240- \\
5039300\end{array}$ & 25960 & 7.0 & 8.5 & 50 & 150 \\
\hline Netarts & $\begin{array}{l}5028820- \\
5023790\end{array}$ & 6980 & 5.5 & 12.4 & 320 & 370 \\
\hline \multicolumn{7}{|l|}{$\operatorname{SLR}(1.0 \mathrm{~m})$} \\
\hline Tillamook & $\begin{array}{l}5063240- \\
5039300\end{array}$ & 25960 & 7.0 & 32.7 & 180 & 280 \\
\hline Netarts & $\begin{array}{l}5028820- \\
5023790\end{array}$ & 6980 & 7.0 & 27.7 & 720 & 770 \\
\hline
\end{tabular}

Notes: The two scenarios of SLR, $0.5 \mathrm{~m}$ and $1.0 \mathrm{~m}$ in 100 years can stand for two rates of accommodation space vertical sand filling to $0.5 \mathrm{~m}$ and $1.0 \mathrm{~m}$ littoral sand thickness in 100 years. Shoreline segment extents or summed lengths $(\mathrm{m})$ that are backed by barrier/dune plains (not sea cliffs) are taken from Table 5 including the full extent of the Tillamook subcell and the southern one half of the Netarts subcell. The deficit volumes derived from estimated submarine accommodation space filling, minus existing active-beach sand volumes and future river sand supply volumes, are from Table 12. The averaged thickness of the back-beach deposits, above MLLW or $0 \mathrm{~m}$ NAVD88 are measured from lidar (2009) and compiled using ArcMap ${ }^{\mathrm{TM}}$. The average active-beach widths of 100 $\mathrm{m}$ (Tillamook subcell) and $50 \mathrm{~m}$ (southern one half of Netarts subcell) are from Table 5.

The total back-beach retreat values predicted for the barrier/dune backed beaches in the Tillamook subcell, as based on the accommodation space approach (Table 13), are greater than those that have been predicted for an equivalent SLR using a modified Bruun's method (Doyle, 1996). For example, Doyle (1996) used a SLR (S) of $1.0 \mathrm{~m}$, a depth (h) of closure (17.5 m water depth), berm (B) heights $(1.3-2.6 \mathrm{~m})$ and across-shelf distances $(\mathrm{L})$ of $(1,430-2,000 \mathrm{~m})$ to predict shoreline retreat $(\mathrm{R})$ in the Tillamook subcell, where $\mathrm{R}=\mathrm{S}\{\mathrm{L} /(\mathrm{B}+\mathrm{h})\}$. Using these relations Doyle (1996) predicted retreat distances of 70-100 m, with a mean and standard deviation of $80 \pm 20 \mathrm{~m}$ $1 \sigma(\mathrm{n}=5)$. The larger total retreat distances reported here for the Tillamook subcell (150-280) (Table 13) are about twice as large as those predicted by Doyle (1996). Adjusting the Bruun's variables to $30 \mathrm{~m}$ depth of closure (h) and distances of $\sim 2,500 \mathrm{~m}$ (L) (Table 8) still yield retreat distances (R) of about one half of those predicted by the accommodation space approach for the Tillamook subcell. More importantly, the accommodation space approach of predicting littoral system responses to near-future SLR, as proposed here, has some advantages over the equilibrium profile method, as developed by Bruun (1962 and 1988). For example, the accommodation space approach can be used to predict sand loss from near-future SLR in shorelines that 1) are not in equilibrium, 2) are underlain by shallow bedrock platforms, 3) vary alongshore in beach back-edge conditions, such as sea cliffs or variable dune topography, 4) are connected to river or estuary sand sources/sinks, and/or 5) are supplied by longshore sand transport (Cooper and Pilkey, 2004; Davidson-Arnott, 2005). For example, the large total-retreat distances predicted for the southern one half of the Netarts subcell (370-770 m), as shown in Table 13, result, in part, from a lack of back-beach sand reserves in the cliff-backed shorelines in the northern one half of the subcell. If the calculated sand deficit to the offshore accommodation space is supplied entirely by the Netarts Bay sand spit, in the southern one half of the subcell, then the potential estimated retreat distance of up to $\sim 0.7 \mathrm{~km}$ for the 1.0 SLR scenario, could eliminate the current narrow sand spit (Figure 8). Based on the study results obtained in the Nehalem, Tillamook, and Netarts subcells, the accommodation space approach used to predict beach sand loss to offshore and estuarine settings, under conditions of potential near-future SLR, should have broad application in other complex littoral systems.

\section{Conclusions}

Three small subcells in the high-wave-energy coast of northern Oregon were evaluated for their susceptibilities to potential near-future sea level rise (SLR) of $0.5-1.0 \mathrm{~m}$, on the bases of estimated beach sand supply and predicted beach sand losses to submarine sand sinks. Marine sand supply to the narrow beaches has diminished in lateHolocene time. The sandy beaches front about $90 \%$ of the study area coastline and longshore transport is restricted over shorter-time scales (multi-decadal) by the largest intervening headlands. Any future accelerations of regional 
sea cliff erosion will not save the existing beaches from predicted near-future sand loss. Local rivers have supplied augite-rich sand directly to the largest subcell, Tillamook, and indirectly from headland-bypassing to the Netarts and Cannon Beach subcells, during late-Holocene time. But potentially-rapid future SLR will increase river sand accommodation spaces in the Tillamook and Nehalem estuaries, thereby reducing or eliminating new river sand supply during the assumed (100 year) period of rapid SLR. The most-important consequences of predicted nearfuture SLR to the narrow active-beaches in the study area are increases in innermost-shelf accommodation spaces. These spaces or areas are located offshore of the study area subcells. During latest-Holocene time gradually increasing accommodation space volume, from $\sim 1.0 \mathrm{~m} \mathrm{ka}^{-1}$ relative SLR in the inner-shelf (to $50 \mathrm{~m}$ water depth), has been, at least partially, back-filled by augite-enriched littoral sand. For the purposes of this article, we use minimum sand accretion rates in the innermost-shelf of the adjacent Columbia River Littoral Cell (to $30 \mathrm{~m}$ water depth) to predict accelerated littoral sand loss to the innermost-shelf areas in the three-subcells study area. Innermost-shelf fill rates of either $1.0 \mathrm{~m}$ per century, or a conservative value of $0.5 \mathrm{~m}$ per century, result in sufficiently-large offshore displacements of existing littoral sand to eliminate all of the active-beaches in the threesubcells study area. The severely eroded beaches that are backed by sea cliffs might host small cobble berms perched on wave-cut platforms 'bedrock', as exposed during low tide levels. Back-beach areas that are developed against Holocene sand spits, foredunes, and/or beach/dune plains (soft shorelines) will further erode (retreat) to compensate for the remaining sand deficits that are owed to the submarine accommodation spaces. Comparisons of soft shoreline retreat distances predicted by the accommodation space approach yielded about twice the magnitude of retreat distances as those predicted by the Bruun's method in the Tillamook subcell. Most importantly, the accommodation space approach, proposed here, is directly applicable to complex littoral systems. For example, such systems might be 1) in across-shore disequilibrium, 2) backed by sea cliffs or topographically-variable barrier/dune deposits, 3) bottomed by indurated wave-cut platforms, and/or 4) linked to river/estuary sand sources or sinks. The flexibility of the accommodation space approach, as used in this article, should have broad applications in other complex littoral systems, facing potential near-future SLR.

\section{Acknowledgements}

Mark Darienzo performed aerial-photo analyses of subcell beach morphology in the study area and compiled Tillamook Bay seismic reflection records and core sample data. Don Pettit, Phil Jackson, Tara Karnes, Charley Clough, Bob Carson, Doann Hamilton, Margot Truini, and Mike Boyer, assisted with beach profiling, beach grain size analyses, beach survey data compilation, and base map drafting in the study area. Jon Kimerling designed the PNW beach database used for this study. Chip Barnett, Sheryl Zinsli, and Kris Vockler assisted with beach profiling in the Tillamook subcell. Ken Cruikshank and David Percy performed beach profiling in the northern Netarts subell. Harry Jol performed GPR analyses of the Netarts Bay spit beach profiles. Scott Williams assisted with GPR surveys of the northern beach profiles in the Tillamook subcell. This research was funded by the National Coastal Resources and Development Institute, under the Coastal Zone Management Program, Oregon, grants No. 2-563203 and CZ17.90-5635-01, and by the NOAA Office of Sea Grant and Extramural Programs, U.S. Department of Commerce, under grant number NA76RG0476, project number R/SD-04, and by appropriations made by the Oregon State Legislature.

\section{Conflict of interests}

The authors declare that there is no conflict of interests regarding the publication of this paper.

\section{Reference}

Allan, J. C., Komar, P. D., \& Priest, G. R. (2003). Shoreline variability on the high-energy Oregon coast and its usefulness in erosion-hazard assessments. Journal of Coastal Research, Special Issue(38), 83-105.

Anderson, T. R., Fletcher, C. H., Barbee, M. M., Frazer, L. N., \& Romine, B. M. (2015). Doubling of coastal erosion under rising sea level by mid-century in Hawaii. Natural Hazards, 78, 75-103. https://doi.org/10.1007/s11069-015-1698-6

Avolio, G. W. (1973). Granulometric analysis of recent sediments of Tillamook Bay, Oregon (p. 61). M.S. Thesis, Portland State University.

Bamber, J. L., Oppenheimer, M., Kopp, R. E., Aspinall, W. P., \& Cooke, R. M. (2019). Ice sheet contributions to future sea-level rise from structured expert judgment. Proceedings of the National Academy of Sciences, 116, 11195-11200. https://doi.org/10.1073/pnas.1817205116

Brunel, C., \& Sabatier, F. (2009). Potential influence of sea-level rise in controlling shoreline position on the French Mediterranean Coast. Geomorphology, 107, 47-57. https://doi.org/10.1016/j.geomorph.2007.05.024

Bruun, P. (1962). Sea-level rise as a cause of shore erosion. Journal of the Waterways and Harbors Division, 88, 
$117-132$.

Bruun, P. (1988). The Bruun rule of erosion by sea-level rise: A discussion on large-scale two-and threedimensional usages. Journal of Coastal Research, 4, 627-648.

Byrnes, M. R., \& Li, F. (1998). Regional analysis of sediment transport and dredged material dispersal patters, Columbia River mouth, Washington/Oregon (p. 53). Final Report to US Army Corps of Engineers Waterways Experiment Station. Applied Coastal Research and Engineering, Inc. Mashpee, MA.

Cooper, J. A. G., \& Pilkey, O. H. (2004). Sea-level rise and shoreline retreat: Time to abandon the Bruun Rule. Global and Planetary Change, 43, 157-171. https://doi.org/10.1016/j.gloplacha.2004.07.001

Darienzo, M. E., \& Peterson, C. D. (1990). Episodic tectonic subsidence of late-Holocene salt marsh sequences in Netarts Bay, Oregon, Central Cascadia Margin, USA. Tectonics, 9, 1-22. https://doi.org/10.1029/TC009i001p00001

Davidson-Arnott, R. G. (2005). Conceptual model of the effects of sea level rise on sandy coasts. Journal of Coastal Research, 21, 1166-1172. https://doi.org/10.2112/03-0051.1

DeConto, R. M., \& Pollard, D. (2016). Contribution of Antarctica to past and future sea-level rise. Nature, 531, 591-597. https://doi.org/10.1038/nature17145

DOGAMI. (2019). Lidar. Department of Geology and Mineral Resources. Retrieved from https://www.oregongeology.org/lidar/

Doyle, D. L. (1996). Beach response to subsidence following a Cascadia subduction zone earthquake along the Washington-Oregon coast (p. 113). M.S. Thesis, Portland State University.

Eilers, H. P. (1974). Plants, plant communities, net production and tide levels; the ecological biogeography of the Nehalem salt marshes, Tillamook County, Oregon (p. 368). Ph.D. Thesis, Oregon State University.

Erlandson, J. M. (2012). As the world warms: Rising seas, coastal archaeology, and the erosion of maritime history. Journal of Coastal Conservation, 16, 137-142. https://doi.org/10.1007/s11852-010-0104-5

Folk, R. L. (1980). Petrology of Sedimentary Rocks (p. 182). Hemphill Publishing Company, Austin Texas.

Glenn, J. L. (1978). Sediment sources and Holocene sedimentation history in Tillamook Bay, Oregon (p. 64). U.S. Geological Survey Open-file Report 78-680. Denver, Colorado. https://doi.org/10.3133/ofr78680

Google Earth. (2019). Google Earth. Retrieved from https://www.google.com/earth/

Hansen, J., Sato, M., Hearty, P., Ruedy, R., Kelley, M., ..., \& Lo, K. W. (2016). Ice melt, sea level rise and superstorms: Evidence from paleoclimate data, climate modeling, and modern observations that $2{ }^{\circ} \mathrm{C}$ global warming could be dangerous. Atmospheric Chemistry and Physics, 16, 3761-3812. https://doi.org/10.5194/acp-16-3761-2016

Hart, R., \& Peterson, C. (2007). Late-Holocene buried forests on the Oregon coast. Earth Surface Processes and Landforms, 32, 210-229. https://doi.org/10.1002/esp.1393

Horning, T. S. (2006). Geologic Hazard Report, Map 2N-NW-32-BC, lot 5100, Rockaway, Tillamook County, Oregon (p. 12). Submitted to Rockaway City Planning Department, Oregon.

Horton, B. P., Khan, N. S., Cahill, N., Lee, J. S., Shaw, T. A., Garner, A. J., Kemp, A. C., Engelhart, S. E., \& Rahmstorf, S. (2020). Estimating global mean sea-level rise and its uncertainties by 2100 and 2300 from an expert survey. npj Climate and Atmospheric Science, 3, 1-8. https://doi.org/10.1038/s41612-020-0121-5

Horton, B. P., Rahmstorf, S., Engelhart, S. E., \& Kemp, A. C. (2014). Expert assessment of sea-level rise by AD 2100 and AD 2300. Quaternary Science Reviews, 84, 1-6. https://doi.org/10.1016/j.quascirev.2013.11.002

Hunger, A. A. (1966). Distribution of Foraminifera, Netarts Bay, Oregon (p. 112). M.S. Thesis, Oregon State University.

Kachel, N. B., \& Smith, J. D. (1986). Geologic impact of sediment transporting events on the Washington continental shelf. In R. J. Knight, \& J. R. McLean (Eds.), Shelf Sands and Sandstones, Canadian Society of Petroleum Geologists, Memoir II (p. 1459162).

Karlin, R. (1980). Sediment sources and clay mineral distributions off the Oregon coast. Journal of Sedimentary Research, 50, 543-559. https://doi.org/10.1306/212F7A4A-2B24-11D7-8648000102C1865D

Kopp, R. E., Gilmore, E. A., Little, C. M., Lorenzo-Trueba, J., Ramenzoni, V. C., \& Sweet, W. V. (2019). AGU Centennial Grand Challenge: Sea-level science on the frontier of usability. Earth's Future. AGU Advancing 
Earth and Space Science, 7, 1235-1269. https://doi.org/10.1029/2018EF001145

Losey, R. J. (2003). Communities and catastrophe: Tillamook response to the AD 1700 earthquake and tsunami, northern Oregon coast (p. 636). Ph.D. Thesis, University of Oregon, Eugene, Oregon.

Masselink, G., \& Russell, P. (2013). Impacts of climate change on coastal erosion. Marine Climate Change Impacts Partnership: Science Review, 2013, 71-86.

Mengel, M., Levermann, A., Frieler, K., Robinson, A., Marzeion, B., \& Winkelmann, R. (2016). Future sea level rise constrained by observations and long-term commitment. Proceedings of the National Academy of Sciences USA, 113, 2597-2602. https://doi.org/10.1073/pnas.1500515113

Meyers, R. A., Smith, D. G., Jol, H. M., \& Peterson, C. D. (1996). Evidence for eight great earthquake-subsidence events detected with ground-penetrating radar, Willapa barrier, Washington. Geology, 24, 99-102. https://doi.org/10.1130/0091-7613(1996)024<0099:EFEGES>2.3.CO;2

Minor, R., \& Peterson, C. D. (2016). Multiple reoccupations after four paleotsunami inundations (0.3-1.3 ka) at a prehistoric site in the Netarts littoral cell, Northern Oregon, USA. Geoarchaeology, 32, 248-266. https://doi.org/10.1002/gea.21593

Mulder, R. A. (1992). Regional tectonic deformation of the northern Oregon coast as recorded by Pleistocene marine terraces (p. 96). M.S. Thesis, Portland State University, Portland, Oregon.

Percy, D. C., Peterson, C. D., \& Cruikshank, K. M. (1998). Collection of ephemeral data on 1997-98 beach erosion at the Capes project within the Netarts littoral cell, Oregon. Final Report to Hart Crower. 10 p. and CD Rom Electronic GIS Files.

Percy, K. L., Bella, D. A., Sutterlin, C., \& Klingeman, P. C. (1974). Description and information sources for Oregon estuaries (p. 294). Oregon Sea Grant College Program. Corvallis, Oregon.

Peterson, C. D., \& Darienzo, M. E. (1989). Preliminary analyses of seismic profile records and dill core samples from Tillamook Bay, Oregon (p. 35). Final Report submitted to Water Resources Division, United States Geological Survey, Denver, Colorado.

Peterson, C. D., \& Peterson, C. A. (2020). Origin of the Camp Westwinds Holocene Sand Ramp, Lincoln County, Oregon: Reconnaissance Field Report (p. 13). Submitted to Camp Westwinds.

Peterson, C. D., Darienzo, M. E., Hamilton, D., Pettit, D. J., Yeager, R. K., Jackson, P. L., Rosenfeld, C. L., \& Terich, T. A. (1994). Cascadia beach-shoreline data base, Pacific Northwest Region, USA. Oregon Department of Geology and Mineral Industries Open-File Report 0-94-2, 29 p. and 3 Electronic Database Files.

Peterson, C. D., Darienzo, M. E., Pettit, D. J., Jackson, P., \& Rosenfeld, C. (1991). Littoral cell development in the convergent Cascadia margin of the Pacific Northwest, USA. In R. Osborne (Ed.), From Shoreline to the Abyss, Contributions in Marine Geology in Honor of F.P. Shepard, SEPM Special Publication (Vol. 46, pp. 17-34). https://doi.org/10.2110/pec.91.09.0017

Peterson, C. D., Doyle, D. L., \& Barnett, E. T. (2000). Coastal flooding and beach retreat from coseismic subsidence in the central Cascadia margin, USA. Environmental and Engineering Geology, 6, 255-269. https://doi.org/10.2113/gseegeosci.6.3.255

Peterson, C. D., Kingen, K. E., Erlandson, J. M., Kaijankoski, P., Meyer, J., \& Ryan, C. (2019). Widespread Evidence of Terminated Marine Transgressive Sand Supply and Failing Longshore Sand Transport to Eroding Coastal Eolian Sand Ramps during the Latest Holocene Time in Oregon and California (Pacific Coast, USA). Journal of Coastal Research, 35, 1145-1163. https://doi.org/10.2112/JCOASTRES-D-19-00013.1

Peterson, C. D., Linde, T. C., \& Vanderburgh, S. (2020). Late-Holocene Shoreline Responses To Competing Shelf, Bay, and Beach Accommodation Spaces Under Conditions of Relative Sea Level Change And The Potential for Future Catastrophic Beach Retreat In The Columbia River Littoral Cell, Washington and Oregon, USA. Marine Geology, 24. https://doi.org/10.1016/j.margeo.2020.106272

Peterson, C. D., Pettit, D. J., Darienzo, M. E., Jackson, P. L., Rosenfeld, C. L., \& Kimerling, A. J. (1991). Regional beach sand volumes of the Pacific Northwest, USA. ASCE Coastal Sediments 91 Proceedings Specialty Conference, 1503-1517.

Peterson, C. D., Stock, E., Hart, R., Percy, D., Hostetler, S. W., \& Knott, J. R. (2009). Holocene coastal dune fields used as indicators of net littoral transport: West Coast, USA. Geomorphology, 116, 115-134. https://doi.org/10.1016/j.geomorph.2009.10.013 
Peterson, C. D., Stock, E., Price, D. M., Hart, R., Reckendorf, F., Erlandson, J. M., \& Hostetler, S. W. (2007). Ages, distributions, and origins of upland coastal dune sheets in Oregon, USA. Geomorphology, 91, 81-102. https://doi.org/10.1016/j.geomorph.2007.02.005

Peterson, C. D., Vanderburgh, S., \& Roberts, M. (2014). Late Holocene Geomorphology of the Columbia River Estuary, Oregon and Washington, USA. Journal of Geography and Geology, 6, 1-27. https://doi.org/10.5539/jgg.v6n2p1

Peterson, C. D., Williams, S. S., Cruikshank, K. M., \& Duprè, J. R. (2010). Geoarchaeology of the Nehalem Spit: Redistribution of Beeswax Galleon Wreck debris by Cascadia earthquake and paleotsunami ( AD 1700), Oregon, USA. Journal of Geoarchaeology, 26, 219-244. https://doi.org/10.1002/gea.20349

Pettit, D. J. (1990). Distribution of sand within selected littoral cells of the Pacific Northwest (p. 249). M.S. Thesis, Portland State University.

Priest, G. R. (1998). The Capes Landslide, Tillamook County, Oregon (p. 10). Oregon Department of Geology and Mineral Industries Open-File Report 0-98-02. Portland, Oregon.

Priest, G. R. (1999). Coastal shoreline change study northern and central Lincoln County, Oregon. In M. Crowell, \& S. P. Leatherman (Eds.), Coastal Erosion Mapping and Management. Journal of Coastal Research, Special Issue(28), 140-157.

Priest, G. R., \& Allan, J. C. (2004). Evaluation of coastal erosion hazard zones along dune and bluff backed shorelines in Lincoln County, Oregon: Cascade Head to Seal Rock (p. 79). Oregon Department of Geology and Mineral Industries, Coastal Field Office.

Revell, D. L., Komar, P. D., \& Sallenger, A. H. (2002). An Application of LIDAR to Analyses of El Niño Erosion in the Netarts Littoral Cell, Oregon. Journal of Coastal Research, 18, 792-801.

Romine, B. M., Fletcher, C. H., Frazer, L. N., \& Anderson, T. R. (2016). Beach erosion under rising sea-level modulated by coastal geomorphology and sediment availability on carbonate reef-fringed island coasts. Sedimentology, 63, 1321-1332. https://doi.org/10.1111/sed.12264

Rosenfeld, C. L. (1977). Cannon Beach: An Integrated Approach to Sand Management (p. 63). Final Report to the City of Canon Beach, Oregon. Submitted September 10, 1977.

Rosenfeld, C. L., Peterson, C. D., Pettit, D. J., Jackson, P. L., \& Kimerling, A. J. (1991). Integrated photogrametric and geophysical monitoring of shoreline instability in littoral cells in the Pacific Northwest. ASCE Coastal Sediments 91 Proceedings, 2214-2222.

Runge, E. J. (1966). Continental shelf sediments, Columbia River to Cape Blanco, Oregon (p. 143). Ph.D. thesis. Oregon State University, Oregon.

Scheidegger, K. F., Kulm, L. D., \& Runge, E. J. (1971). Sediment sources and dispersal patterns of Oregon continental shelf sands. Journal of Sedimentary Petrology, 41, 1112-1120. https://doi.org/10.1306/74D724142B21-11D7-8648000102C1865D

Shaw, J., Taylor, R. B., Solomon, S., Christian, H. A., \& Forbes, D. L. (1998). Potential impacts of global sea-level rise on Canadian coasts. Canadian Geographer/Le Géographe canadien, 42, 365-379. https://doi.org/10.1111/j.1541-0064.1998.tb01352.x

Sternberg, R. W. (1986). Transport and accumulation of river-derived sediment on the Washington continental shelf, USA. Journal of the Geological Society, London, 143, 945-956. https://doi.org/10.1144/gsjgs.143.6.0945

Sternberg, R. W., \& Larsen, L. H. (1976). Frequency of sediment movement on the Washington continental shelf: A note. Marine Geology, 21, M37-M47. https://doi.org/10.1016/0025-3227(76)90056-6

Stive, M. J. (2004). How important is global warming for coastal erosion? Climatic Change, 64, 27. https://doi.org/10.1023/B:CLIM.0000024785.91858.1d

Terich, T. (1973). Bayocean Spit, Tillamook, Oregon; early economic development and erosion history (p. 145). $\mathrm{Ph} . \mathrm{D}$. Thesis, Oregon State University.

Toimil, A., Losada, I. J., Camus, P., \& Díaz-Simal, P. (2017). Managing coastal erosion under climate change at the regional scale. Coastal Engineering, 128, 106-122. https://doi.org/10.1016/j.coastaleng.2017.08.004

Venkatarathnam, K., \& McManus, D. A. (1973). Origin and distribution of sands and gravels on the northern continental shelf of Washington. Journal of Sedimentary Petrology, 43, 799-811. 
https://doi.org/10.1306/74D72874-2B21-11D7-8648000102C1865D

Walkden, M., \& Dickson, M. (2008). Equilibrium erosion of soft rock shores with a shallow or absent beach under increased sea level rise. Marine Geology, 251, 75-84. https://doi.org/10.1016/j.margeo.2008.02.003

Wiedemann, A. M. (1990). The coastal parabolic dune system at Sand Lake, Tillamook County, Oregon, USA. In R. Davidson-Arnott (Ed.), Proceedings of the Symposium on Coastal Sand Dunes 1990. National Research Council, Ottawa, 341-358.

Wilcoxen, P. J. (1986). Coastal erosion and sea level rise: Implications for ocean beach and San Francisco's Westside Transport Project. Coastal Management, 14, 173-191. https://doi.org/10.1080/08920758609362001

Zhang, K., Douglas, B. C., \& Leatherman, S. P. (2004). Global warming and coastal erosion. Climatic change, 64, 41. https://doi.org/10.1023/B:CLIM.0000024690.32682.48

\section{Copyrights}

Copyright for this article is retained by the author(s), with first publication rights granted to the journal.

This is an open-access article distributed under the terms and conditions of the Creative Commons Attribution license (http://creativecommons.org/licenses/by/4.0/). 